UNITED STATES DEPARTMENT OF THE INTERIOR

GEOLOGICAL SURVEY

\title{
TITANIUM-ZIRCONIUM-RARE-EARTH PLACER RESOURCES \\ POTENTIAL OF SURFICIAL SEDMMENTS ON THE ATLANTIC \\ CONTINENTAL SHELF OFFSHORE OF NEW YORK, RHODE \\ ISLAND, AND SOUTHERN MASSACHUSETTS
}

by

Andrew E. Grosz ${ }^{1}$ and William M. Kelly ${ }^{2}$

Open-File Report 91-391

Prepared in cooperation with the New York state Geological survey

This report is preliminary and has not been reviewed for conformity with 0.8. Geological survey editorial standards and stratigraphic nomenclature. Use of trade names does not constitute endorsement by the U.8. Geological survey.

${ }^{1}$ U.S. Geological Survey

Reston, VA, 22092

${ }^{2}$ N.Y. State Geological Survey

Albany, NY, 12230 
TITANIUM-ZIRCONIUM-RARE-EARTH PLACER RESOURCES POTENTIAL OF SURFICIAL SEDIMENTS ON THEE ATLANTIC CONTINENTAL SHELF OFFSHORE OF NEW YORK, RHODE ISLAND, AND SOUTHERN MASSACHUSETTS

by

Andrew E. Grosz and William M. Kelly

Table of Contents

ABSTRACT

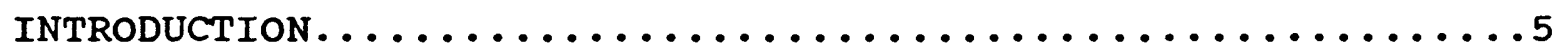

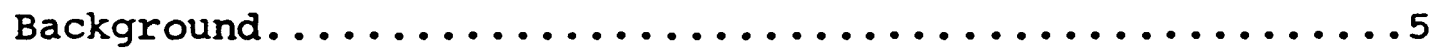

Physiography.............................

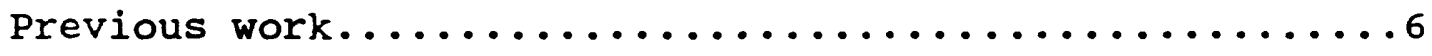

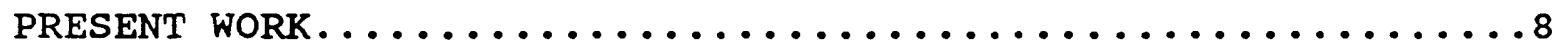

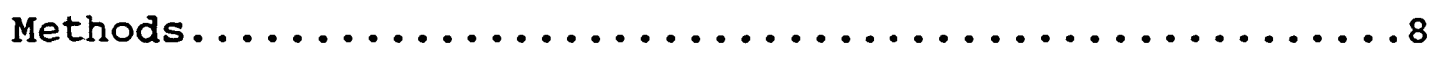

Sample acquisition..................

Laboratory procedures...................

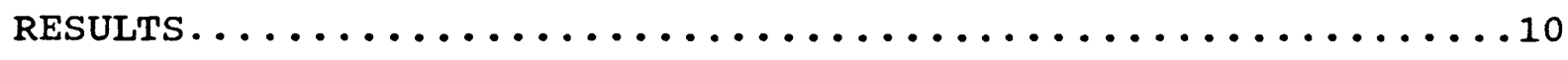

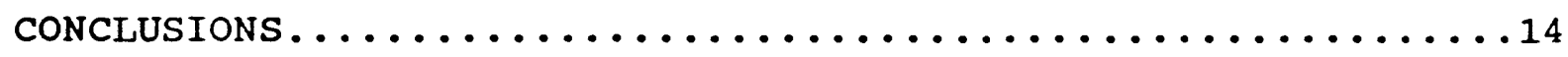

ACKNOWLEDGMENTS........................... 15

REFERENCES.............................. 16 


\section{FIGURES}

Figure 1.--Map showing the locations of the surface grab samples

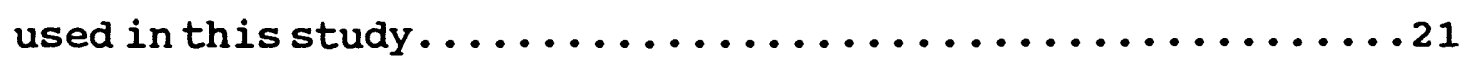

Figure 2.--Plot showing the relationship between mean grain size and gamma activity of bulk sediments................22

Figure 3.--Plot showing the relationship between the percentage of monazite + zircon and gamma activity of bulk sediments...23

Figure 4.--Contour plot showing areas of higher radioactivity in the study area.............................24

Figure 5.--Contour plot showing areas of high silt + clay content

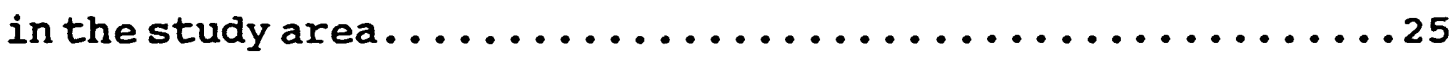

Figure 6.--Plot showing the relationship between heavy-mineral

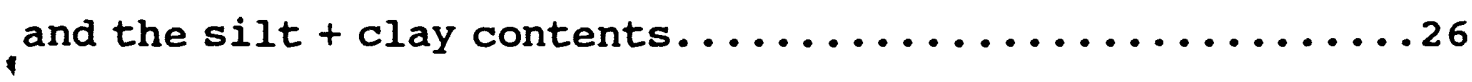

Figure 7.--Contour plot showing the percentage of heavy minerals in

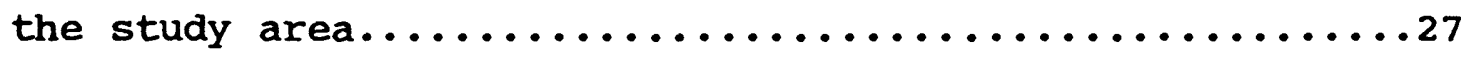

Figure 8.--Contour plot showing the percentage of economic heavy minerals (bulk sample basis) in the study area........28

\section{TABLES}

Table 1.--Location coordinates and lithologic descriptions of the

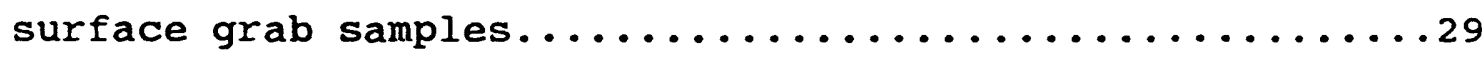

Table 2.--Water depth, textural, carbonate content, and gamma radiation activity data for the surface grab samples....31

Table 3.--Feldspar and heavy-mineral data for the surface grab

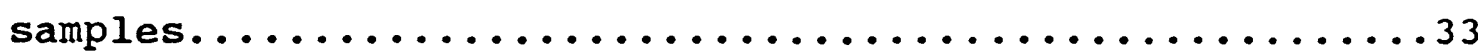




\section{ABSTRACT}

Textural and mineralogic data from eighty-three grab samples from the Atlantic Continental Shelf offshore of New York, Rhode Island, and southern Massachusetts are used to determine the potential for placer heavy-mineral resources in surficial sediments.

The sediments on this portion of the U.S. Atlantic Shelf were deposited largely by glacial and periglacial processes within the past 18,000 years. They are composed predominantly of quartz and rock fragments; shell fragments are only locally important constituents. In the eastern portion of the study area the sediments are finer grained than to the west, and a coastparallel zone of coarser grained sediments approximately coincident with the $40 \mathrm{~m}$ isobath is evident offshore of Long Island.

The sediments average $2.58 \%$ by weight heavy minerals with a standard deviation of 1.80. The species composing the bulk of the heavy-mineral suite, in decreasing order of abundance, are pyroboles, garnet, aluminosilicates, tourmaline, epidote, staurolite, ilmenite, magnetite, zircon, rutile, sphene, leucoxene (altered ilmenite), and monazite. other, infrequently occurring minerals in the heavy-mineral assemblage include quartz with inclusions, rock fragments, micas, hematite (including concretions), pyrite and/or marcasite, spinels, glauconite, scheelite, shell fragments, flyash (anthropogenic), clayballs, corundum, apatite, and unidentified opaques and nonopaques. 
The economically important heavy minerals ilmenite (including altered ilmenite), rutile, zircon, monazite, and aluminosilicates make up an average of $0.57 \%$ by weight of the bulk sediments with a standard deviation of 0.46 . The titanium minerals (exclusive of sphene) constitute an average $6.5 \%$ by weight of the heavy-mineral assemblage and range 1.0 to $22.6 \%$. These values are far below currently mined ores onshore and are substantially below values found elsewhere on the U.S. Atlantic Shelf.

The potential for placer deposits of heavy minerals appears to be limited with respect to other portions of the U.S. Atlantic Continental Shelf by low overall concentrations of heavy minerals, and these have only small economic heavy-mineral components. Fluvial channels may also host placer mineral concentrations. However, the immature nature of the fluvial sediments coupled with lack of weathering of their heavy-mineral suite limits their potential. Although the radioactive heavy minerals zircon + monazite appear to control the radioactivity of the sediments in the study area gamma-radiation surveys would be little use in locating surface concentrations of heavy minerals. Areas of higher radioactivity are coincident with finer grained sediments devoid of (or relatively depleted in) heavy minerals. 


\section{INTRODUCTION}

\section{Background}

The proclamation of the United States Exclusive Economic Zone (EEZ) in March 1983 nearly doubled the jurisdictional area of the United States. Although the location, concentration, and abundance of resources in the EEZ are poorly understood, many strategic, critical, and industrial minerals are known to exist.

As part of a larger effort to assess the mineral resource potential of the sediments within the U.S. EEZ, grain-size distribution data were compiled and mineralogic data were generated for 83 surface grab samples that were collected from the Atlantic Continental Shelf (ACS) offshore of New York, Rhode Island, and southern Massachusetts.

\section{Physiography}

South of New York City, the shelf is approximately $190 \mathrm{~km}$ wide; the shelf break is in the vicinity of the 160-m isobath. The shelf surface is not a smooth plain; its physiographic features include erosional channels and terraces and depositional sand swells (Uchupi, 1968). The largest erosional feature in this area is a submerged Hudson River channel, $27 \mathrm{~km}$ wide at its mouth, which extends from the mouth of the Hudson River $170 \mathrm{~km}$ to the Hudson Canyon at the shelf edge. The channel was cut by the Hudson River during the Pleistocene Epoch when sea level was near the shelf edge (Uchupi, 1968). A series of terraces thought to be ancient beaches (Uchupi, 1968) are indicated at the 35-, 43-, 55-, 63-, 80-, 125-, 158-, and 210-m isobaths. Other features on 
the shelf include numerous shoals, some of which may be seaward extensions of glacial moraines.

\section{Previous work}

Schlee (1973) and Hollister (1973) showed that the surficial sediments in the study area are predominantly unimodal wellsorted sands except near the shelf edge offshore of MA, where the sediments are largely bi- or polymodal more poorly sorted silts and sandy silts. Gravel occurs in scattered discontinuous patches. Trumbull (1972) discussed the sand-size fraction of the sediments in the study area, and schlee and pratt (1970) discussed the composition and distribution of gravels.

Ross (1970) was among the first to report on the composition of heavy-mineral (HM) assemblages in the area of this study. In a regional study Ross addressed small-scale compositional trends; HM analyses were done in an effort to outline broad petrographic provinces. HM contents were determined as percentages of the sand-size fraction. Qualitative analyses of the HM assemblages provided mineral abundance data on non-opaque minerals only; opaque minerals such as magnetite, ilmenite, altered ilmenite (leucoxene), black rutile, cassiterite, and others were grouped into an undifferentiated "opaques" category, and highly altered minerals were reported as "altered grains." Tabulated analyses were not given; the information was presented graphically.

The first published analysis of economic HMs in the region of this study was given by Drucker (1983). Based on petrographic analyses of HMs separated from 92 surface grab samples (and use 
of adjunct seismic data) in the western portion of our study area, Drucker calculated 7 million dry tons of ilmenite to be present within three zones. It is not clear what procedures Drucker used to identify the opaque minerals that were mounted on slides and examined with a polarizing microscope. The data, however, appear to be internally inconsistent because it is not possible to distinguish between ilmenite, magnetite, titanomagnetite, leucoxene, and other opaque minerals with a polarizing microscope. Drucker also presents his mineralogic data graphically which does not allow for rigorous comparisons with the data of this study.

General placer HM distribution patterns in surficial sediments of the U.S. ACS were discussed by Grosz and others (1986), and an assessment of the economic HM resource potential was given by Grosz (1987). The patterns of distribution of individual HM species for ACS sediments were given by Grosz and Escowitz (1983), Grosz (1987), Grosz and others (1987), Grosz and others (1989a,b,c), Grosz and Nelson (1989), and Grosz and others (1990). These studies do not, however, provide mineralogic data for the shelf area of this study.

Thus, available literature for the area of this study provides HM data that were generated for regional studies or appear to be internally inconsistent. Analyses limited to nonopaque mineral species of narrow size fractions of small sediment samples do not provide adequate information for an assessment of detrital mineral resource potential. In addition, the use of 
very small samples creates a particle-sparsity-effect (Clifton and others, 1969), which makes difficult the accurate determination of scarce but highly valuable mineral species such as monazite.

\section{PRESENT WORK}

This study is based on 83 surface grab samples from the ACS offshore of NY, RI, and southern MA. The sample density (about 1 per $450 \mathrm{~km}^{2}$ ), however, allows only for the definition of smallscale patterns. The 83 surface grab samples were collected on an approximate $20 \mathrm{~km}$ grid; coverage extends from the 9 to the $292 \mathrm{~m}$ isobath.

\section{Methods}

Sample acquisition

The samples in this study are part of a group of about 3600 ocean-floor sediment grab samples collected from the Acs jointly by the Woods Hole Oceanographic Institution and the U.S. Geological Survey (Hathaway, 1971). The sediment sample collection was conducted between 1955 and 1970 by using several types of bottom samplers, including Campbell, Smith-McIntyre, Van Veen, and Dietz-Lafond; the samples used in this study were collected during June 1962, October 1963, July and August 1964, and August 1965. The samples were located largely by means of a 20-km grid; the precision of the locations is estimated to be within about 1 nm (Figure 1). The grab samples may not accurately represent the bulk ocean-floor sediments, however, because part of the fine- 
grained material may have been lost from coarse grained or gravelly sediments during collection.

\section{Laboratory procedures}

An average of $180 \mathrm{~g}$ of bulk sample with a standard deviation (S.D.) of 62.54 was split and sieved in dry condition into the following textural classes: (1) gravel and very coarse sand (>16 mesh, >1.18 mm), (2) coarse- to very fine-grained sand (from <16 to $>325$ mesh, <1.18 - >0.045 mm), and (3) silt + clay (<325 mesh, $<0.045 \mathrm{~mm})$. The HM fraction of the coarse- to very fine-grained sand fraction was separated by using bromoform (SG >2.85). As large a split as could be derived from the original sample was used for the separation of HMs because some important mineral species, such as monazite, are typically present in very small quantities. Smaller samples are less likely to contain representative amounts of rare minerals.

HM concentrates exceeding about $2.0 \mathrm{~g}$ in mass were separated into three magnetic subfractions on a Frantz Isodynamic Magnetic Mineral Separator $(0.0-0.5,0.5-1.0$, and $>1.0 \mathrm{~A})$ after the highly magnetic minerals were removed by using a hand-held magnet. Each of the four subfractions was weighed and studied independently by using petrographic and reflected light microscopes. The identification of some minerals was made by $\mathrm{X}$-ray diffraction. Comparison charts for the visual estimation of percentage composition (Terry and Chillingar, 1955) and pointcounting were utilized to estimate mineral abundances in each magnetic subfraction. The identification of zircon and monazite 
was aided by using long- and short-wave ultraviolet illumination. Abundances of individual mineral species in each magnetic subfraction were summed and calculated as weight percentages of the total HM fraction without compensation for differences in densities of individual mineral species. Lithologic descriptions, the results of these mineralogic determinations, and textural and limited mineralogic data compiled by Hathaway (1971) are given in Tables 1, 2, and 3. The data are given as weight percentages unless otherwise noted.

\section{RESULTS}

The sediments in the study area are predominantly unimodal quartz sands. The sand-size fraction averages $88.7 \%$ (S.D. 17.5); gravel content averages $2.6 \%$ (S.D. 7.9), and silt + clay content averages $3.6 \%$ (S.D. 6.2) (Table 2). Quartz is the dominant component of the sand-size fraction accounting for an average of $78.55 \%$ (S.D. 16.93). The mean grain size of the sediments averages $0.28 \mathrm{~mm}$ (medium sand) (S.D. 0.21 ; medium silt to very coarse sand) (Table 2). Carbonate content, principally in the form of shells, shell fragments, and foraminiferal tests averages $2.30 \%$ (S.D. 2.64) of the sand-size fraction (Table 2).

The total feldspar content of the sand-size fraction averages $11 \%$ (S.D. 8). Potash feldspar, averaging $6 \%$ (S.D. 7), is more abundant than plagioclase feldspar which averages $5 \%$ (S.D. 6) (Table 3).

The sediments contain an average $2.58 \%$ (S.D. 1.80) HM; labile minerals (magnetite, pyroboles, garnet, and epidote) 
comprise an average of $53.3 \%$ (S.D. 13.3) of the HMs. Although there are variations apparently related to water depth and depositional environment, the frequencies of occurrence (in decreasing order of abundance) of the HMs for the sample population are pyroboles (undifferentiated pyroxenes and amphiboles), garnet, aluminosilicates (sillimanite, kyanite, and andalusite), tourmaline, epidote, staurolite, ilmenite, magnetite, zircon, rutile, sphene, leucoxene (altered ilmenite), and monazite. other, infrequently occurring minerals in the heavymineral assemblage include quartz with inclusions, rock fragments, micas (chlorite, biotite, occasional muscovite), hematite (including concretions), pyrite and/or marcasite (as filling of foraminiferal tests), spinels, glauconite, scheelite, shell fragments, flyash (anthropogenic), clayballs, corundum, apatite, and unidentified opaques and nonopaques. The results of mineralogic analyses are given on Table 3 .

The detrital minerals of possible commercial interest on the study area shelf consist of ilmenite, leucoxene (altered ilmenite), rutile, zircon, monazite, and aluminosilicates (sillimanite, kyanite, and andalusite). Other HM species such as sphene, staurolite, tourmaline, and garnet have industrial applications and are valuable but are not included in this analysis. The variable EHM/T (Table $3 ;$ the sum of the economic heavy minerals ilmenite + leucoxene + rutile + zircon + monazite + aluminosilicates expressed as a percentage of the bulk sample, 
T) is used as a measure of the potential for commercial deposits that the surficial sediments may have.

EHM/T averages $0.57 \%$ (S.D. 0.46$)$ and exhibits a general decrease with increasing mean grain size of the bulk sediments. Factors that limit the potential for significant concentrations of economic HMs include the juvenile nature of the HM assemblage and the low overall abundance of HMs in the sediments of the study area. The HM assemblage deposited in the study area shelf is ubiquitousiy juvenile, upgrading of the assemblages by weathering does not appear to be significant or areally extensive, and textural and mineralogic data do not provide supporting evidence for significant sea-level stillstands (necessary for the formation of large placer deposits). As marine transgressions may be effective dispersing agents of beach-complex sands, the preservation potential of beach-complex-associated deposits of HMs on the study area shelf is low. Although it is possible that small remnants of basal portions of larger HM deposits may exist, their expression would be difficult to detect with broad surface grab sampling grids; sampling at depth is necessary.

Although the potential for detrital HM resources in the surficial sediments of the study area is low with respect to other portions of the U.S. ACS, concepts and data of use to their exploration are provided for future studies. Gamma radioactivity measurements for some of the samples used in this study were made by C.L. Schelske (Emery and Uchupi, 1972). The measurements were made by use of a scintillation counter capable of plotting gamra 
radiation in a spectrum over 0 to $3 \mathrm{MeV}$. Schelske observed that the most prominent peak in the spectrum was at $1.43 \mathrm{MeV}$ for $\mathrm{K}^{40}$; lesser peaks included those for $\mathrm{Th}^{232}$ and $\mathrm{U}^{238}$. Peaks for manmade radioelements were subordinate or absent. The total counts were corrected for sample weight, volume, shape of container, and background count and are reported as counts per minute per gram (CPM/g; Table 2). Radioactive minerals in the samples include light (SG <2.85) and heavy minerals. The light minerals may include mica, feldspars, illite, and glauconite. Some glauconite may sink in bromoform, but, in our experience, most remains with the light mineral fraction. Mica, the feldspars, illite, and glauconite are radioactive because of their $\mathrm{K}^{40}$ content. The HMs (and their radioelements) include monazite (Th, $U$ ), zircon ( $U$, Th), phosphate and apatite (U, Th), sphene (U, Th), and epidote group minerals (U, Th). Other sources of gamma radiation in marine sediments may include radioelements adsorbed onto iron oxides and in organic matter (Grosz, 1991).

Finer grained sediments tend to have higher radioactivity than coarser sediments (Figure 2), and the overall radioactivity of the sediments appears to be controlled by the distribution of zircon + monazite (Figure 3). A contour plot of the gamma radiation data (Figure 4 ) shows that higher radiation values are found associated with areas where finer grained sediments prevail (Figure 5). Because finer grained sediments contain smaller quantities of heavy minerals (Figure 6), gamma radiation highs in the area of this study, unlike elsewhere on the U.S. ACS (Grosz, 
1991), are of little value in defining areas of where economic heavy minerals are preferentially concentrated.

Concentrations of HMs on the Shelf area of this study do not parallel the coastline, but rather appear to be distributed in two coast-oblique bands extending in a southeasterly direction offshore of western and central Long Island (Figure 7). The distribution of the economically important heavy minerals (EHM/T) follows this same pattern (Figure 8 ).

\section{CONCLUSIONS}

The placer resource potential of the surficial sediments in the study area is limited by the immature HM suite that has been provided by periglacial processes through the time interval that the sediments have accumulated. The data indicate that the surficial sediments in the study area have a low overall potential for titanium-zirconium-rare-earth-bearing placers, although higher concentrations in some samples may indicate locally greater potential. An additional constraint is the absence of extensive discernible depositional beach-complex sediments. 


\section{ACKNOWLEDGMENTS}

We extend our appreciation to J.C. Hathaway of the USGS at Woods Hole, MA for supervising the heavy-liquid separation and magnetic fractionation of some of the samples. We are also indebted to J.R. Albanese, of the State University of New York, oneonta for his assistance with the HM data reduction. W.J. Greenwood and A.R. Gadgil, Volunteers for Science at the USGS in Reston, VA drafted some of the figures. This study was funded, in part, by a grant from the Minerals Management Service through the Texas Bureau of Economic Geology under Cooperative Agreement 14-12-0001-30432 to the New York State Geological Survey. 


\section{REFERENCES}

Clifton, H.E., Hunter, R.E., Swanson, F.J., and Phillips, R.L., 1969, Sample size and meaningful gold analysis: U.S. Geological Survey Professional Paper 625-C, 19 p.

Drucker, B.S., 1983, Distribution and analysis of selected economic heavy mineral species within the inner New York Bight: Proceedings of the 15th Annual offshore Technology Conference, Houston, Texas, May 2-5, 1983, pp. 427-430.

Emery, K.O., and Uchupi, Elazar, 1972, Western North Atlantic ocean: topography, rocks, structure, water, life, and sedi, ments: American Association of Petroleum Geologists Memoir $17,532 \mathrm{p}$.

Force, E.R., Grosz, A.E., Loferski, P.J., and Maybin, A.H., 1982, Aeroradioactivity maps in heavy-mineral Exploration--Charleston, South Carolina, area: U.S. Geological Survey Professional Paper 1218, 19 p.

Grosz, A.E., 1983, Application of total count aeroradiometric maps to the exploration for heavy mineral deposits in the Coastal plain of Virginia, with a section on Field-spectrometer-data reduction by Kenneth L. Kosanke: U.S. Geological Survey Professional Paper 1263, 20 p. 
-1987, Nature and distribution of potential heavy-mineral resources offshore of the Atlantic Coast of the United States: Marine Mining, v. 6, p. 339-357.

Grosz, A.E., 1991 (in press), Exploration for submarine mineral deposits by use of gamma-ray radiometric methods, in, Geyer, R.A., and Grosz, A.E., eds., Handbook of Geophysical Exploration at Sea, CRC Press, Inc., Boca Raton, Florida, 49 manuscript pages.

Grosz, A.E., Cathcart, J.B., Macke, D.L., Knapp, M.S., Schmidt, Walter, and Scott, T.M., 1989a, Geologic interpretation of the gamma-ray aeroradiometric maps of central and northern , Florida: U.S. Geological Survey Professional Paper 1461, 48 p.

Grosz, A.E., and Escowitz, E.C., 1983, Economic heavy minerals of the U.S. Atlantic Continental Shelf, in Tanner, W.F., ed., Symposium on Coastal Sedimentology, 6th, Tallahassee, 1983, Proceedings: Tallahassee, Florida State University, p. 234242 . 
Grosz, A.E., Hathaway, J.C., and Escowitz, E.C., 1986, Placer deposits of heavy minerals in Atlantic continental Shelf sediments: Proceedings of the 18th Annual offshore Technology Conference, Houston, Texas, May 5-8, OTC 5198, p. 387-394.

Grosz, A.E., Hoffman, C.W., Gallagher, P.E., Reid, J.C., and Hathaway, J.C., 1990, Heavy-mineral resource potential of surficial sediments on the Atlantic continental shelf offshore of North Carolina: A reconnaissance study: U.S. Geological Survey Open-File Report 90-0245, 58 p.

Grosz, A.E., Muller, F.E., Uptegrove, Jane, Farnsworth, John, Bell, Christy, Maharaj, S.V., Muessig, Karl, and Hathaway, J.C., 1989b, Textural, physiographic, bathymetric, and geologic factors controlling economic heavy minerals distribution in surficial sediments on the Atlantic Continental Shelf offshore of New Jersey: U.S. Geological Survey Open-File Report 89-0683, 32 p.

Grosz, A.E., and Nelson, D.D., 1989, Textural and mineralogic analyses of surficial sediments offshore of Myrtle Beach,South Carolina: U.S. Geological Survey open-File Report $89-0168,23 \mathrm{p}$. 
Grosz, A.E., Nocita, B.W., Kohpina, Pramuan, Olivier, M.M., and Scott, T.M., 1989c, Preliminary grain-size, and mineralogic analyses of vibracore samples from the Inner continental Shelf offshore of Cape Canaveral, Florida: U.S. Geological Survey Open-File Report 89-0018. 22 p.

Hathaway, J.C., 1971, Data file, Continental Margin Program, Atlantic coast of the United States, v. 2, Sample collection and analytical data: Woods Hole Oceanographic Institution Reference Number 71-15, $486 \mathrm{p}$.

Hollister, C.D., 1973, Atlantic continental shelf and slope of the United States - Texture of surface sediments from New J'ersey to Florida: U.S. Geological Survey Professional Paper $529-\mathrm{M}, 23 \mathrm{p}$.

Ross, D.A., 1970, Atlantic continental shelf and slope of the United States - Heavy minerals of the continental margin from southern Nova Scotia to northern New Jersey: U.S. Geological Survey Professional Paper 529-G, $40 \mathrm{p}$.

Schlee, John, 1973, Atlantic continental shelf and slope of the United States - Sediment texture of the northeastern part: U.S. Geological Survey Professional Paper $529-\mathrm{L}, 64$ p. 
Schlee, John, and Pratt, R.M., 1970, Atlantic continental shelf and slope of the United States - Gravels of the northeastern part: U.S. Geological Survey Professional Paper $529-\mathrm{H}, 39 \mathrm{p}$.

Terry, R.D., and Chillingar, G.V., 1955, Comparison charts for visual estimation of percentage composition: Journal of Sedimentary Petrology, v. 25, p. 229-234.

Trumbull, J.V.A., 1972, Atlantic continental shelf and slope of the United States - Sand-size fraction of bottom sediments, New Jersey to Nova Scotia: U.S. Geological Survey Professional Paper 529-K, 45 p.

Uchupi, Elazar, 1968, Atlantic continental shelf and slope of the United States--Physiography: U.S. Geological Survey Professional Paper 529-C, 30 p. 


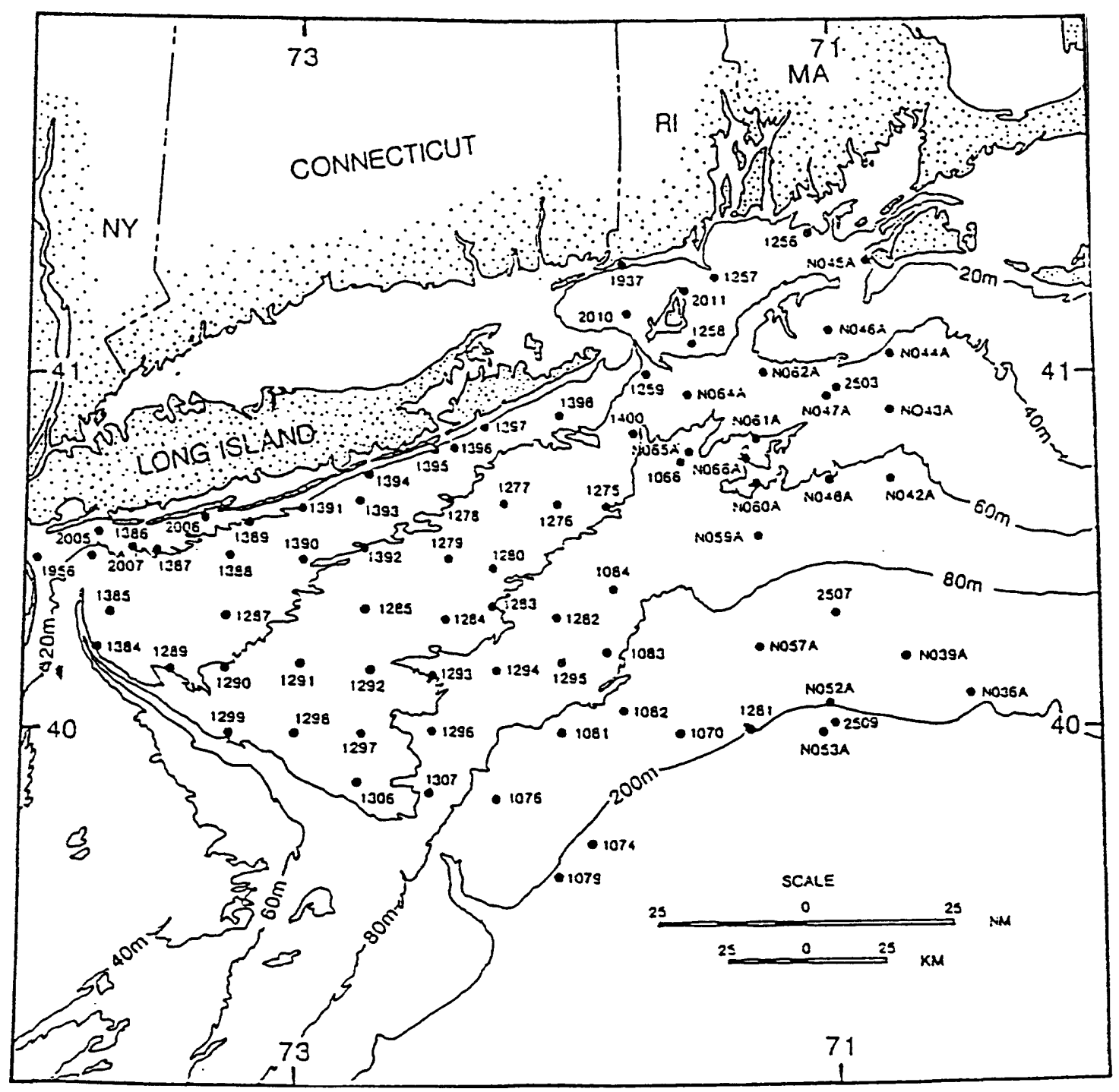

Figure 1.--Map showing the locations of the surface grab samples used in this study. 


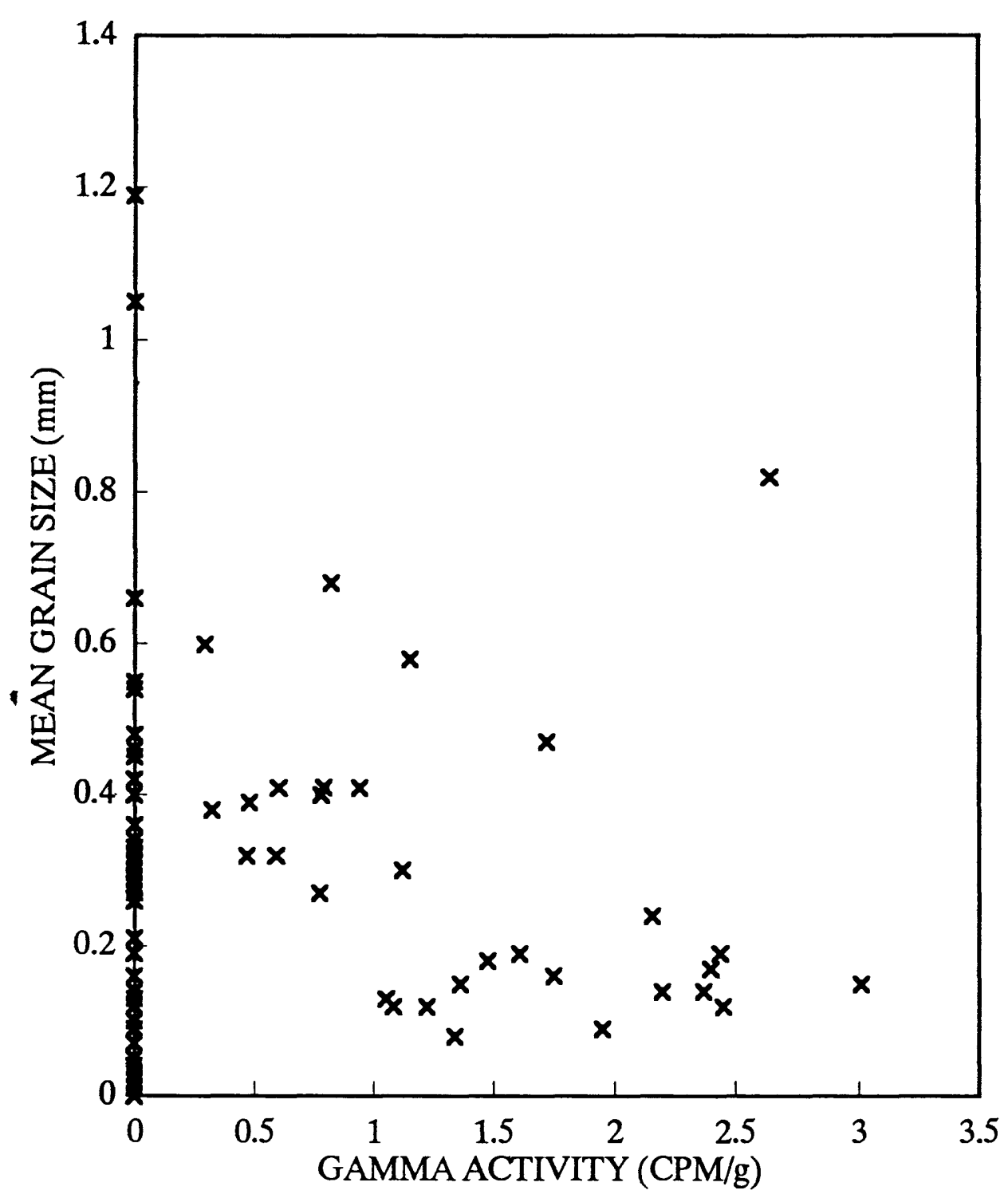

Figure 2.--Plot showing the relationship between mean grain size and gamma activity of bulk sediments. 


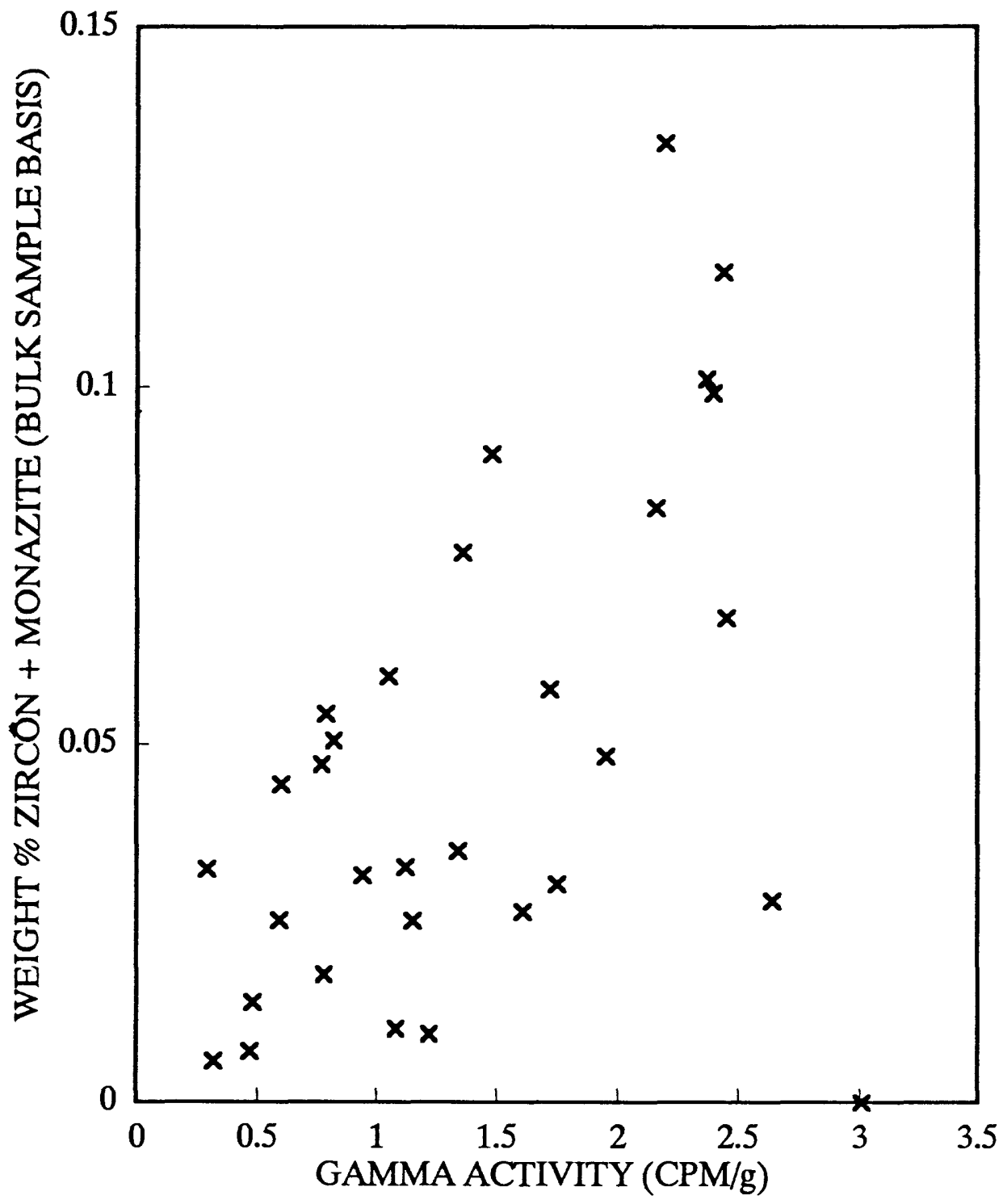

Figure 3.--Plot showing the relationship between the percentage of monazite + zircon and gamma activity of bulk sediments. 


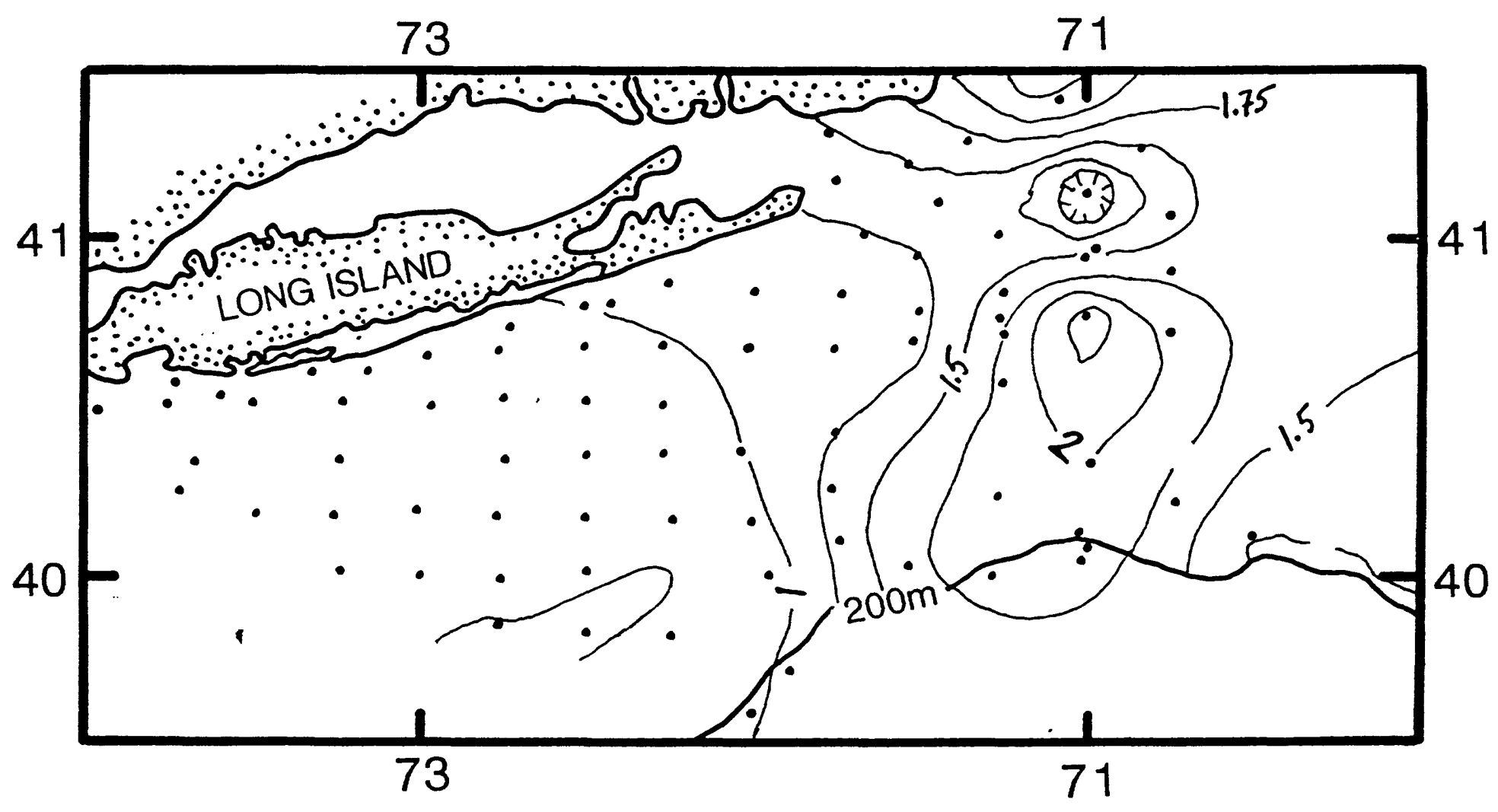

Figure 4.--Contour plot showing areas of higher radioactivity in the study area. Contour interval $0.25 \mathrm{CPM} / \mathrm{g}$. 


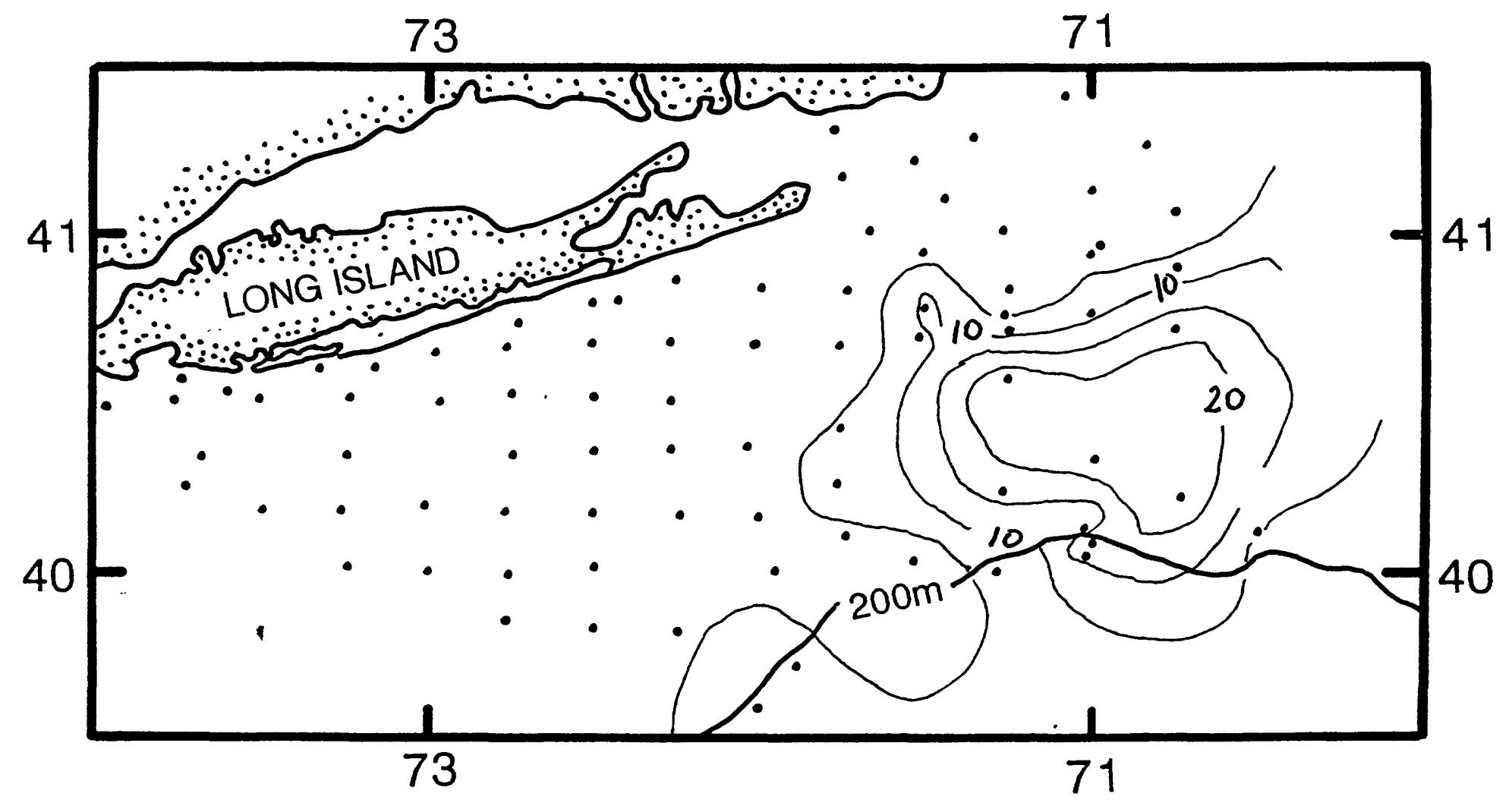

Figure 5.--Contour plot showing areas of high silt + clay content in the study area. Contour interval 5 percent. 


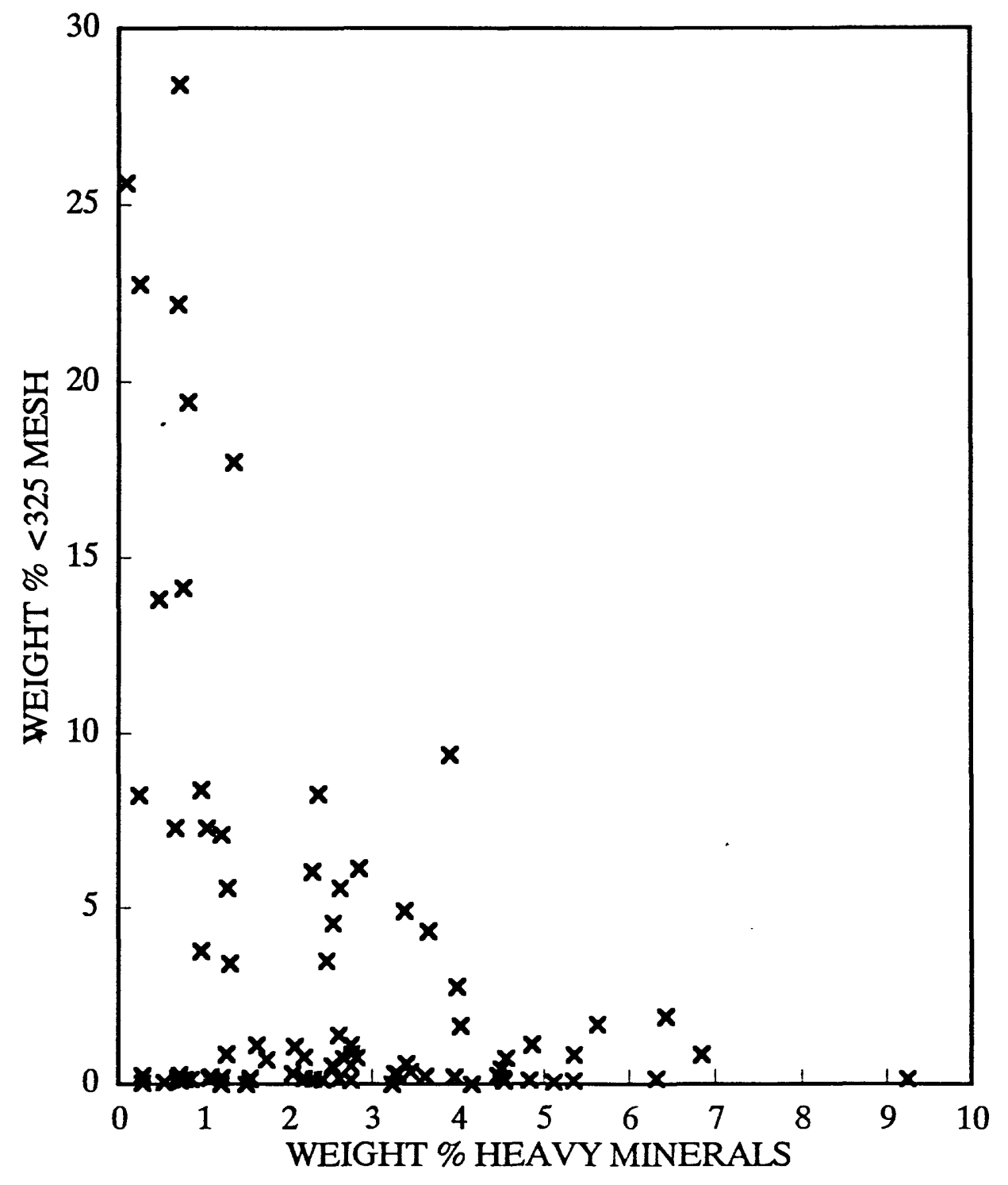

Figure 6.--Plot showing the relationship between heavy-mineral and the silt + clay contents. 


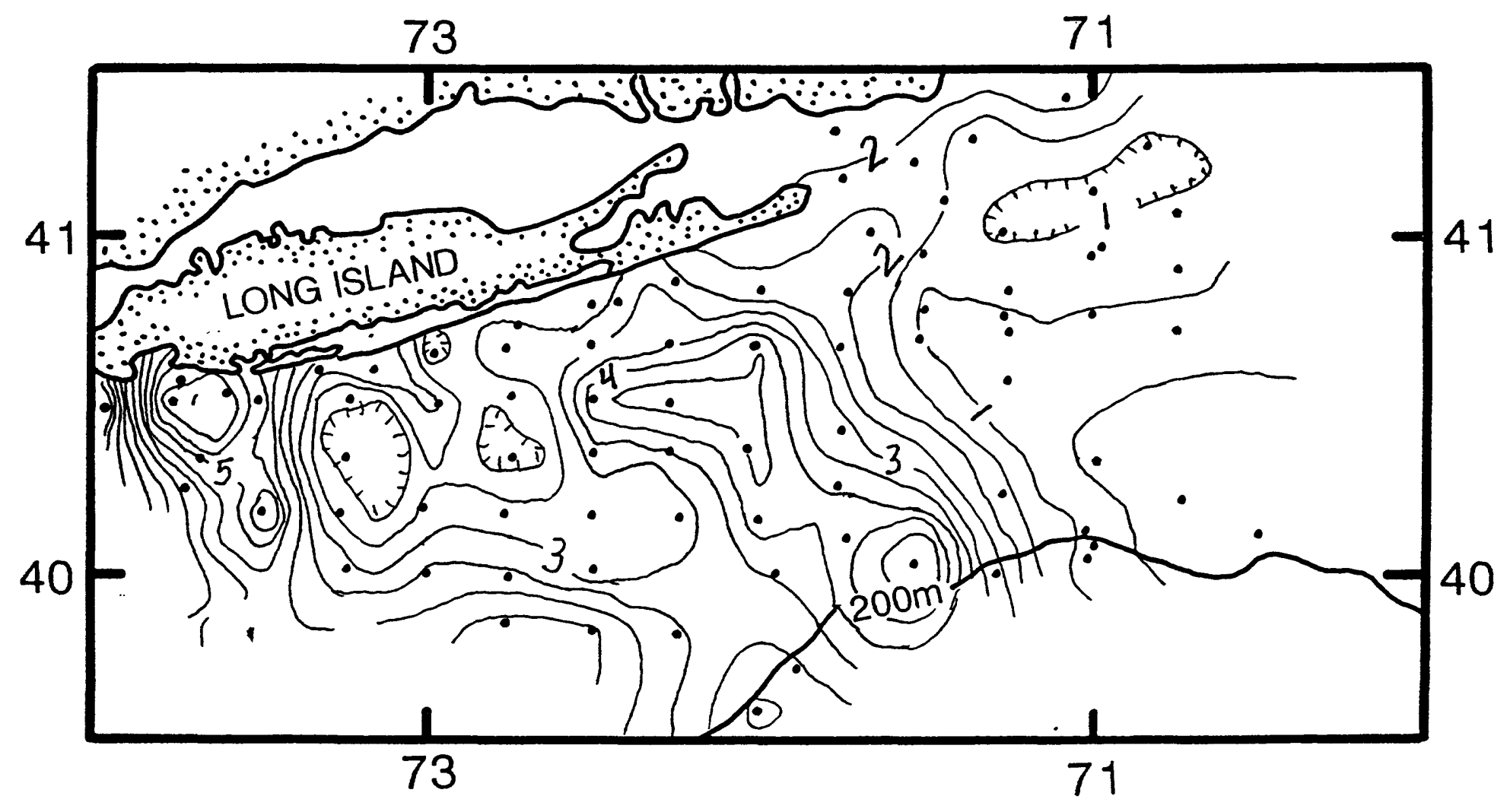

Figure 7.--Contour plot showing the percentage of heavy minerals in the study area. Contour interval 0.5 percent. 


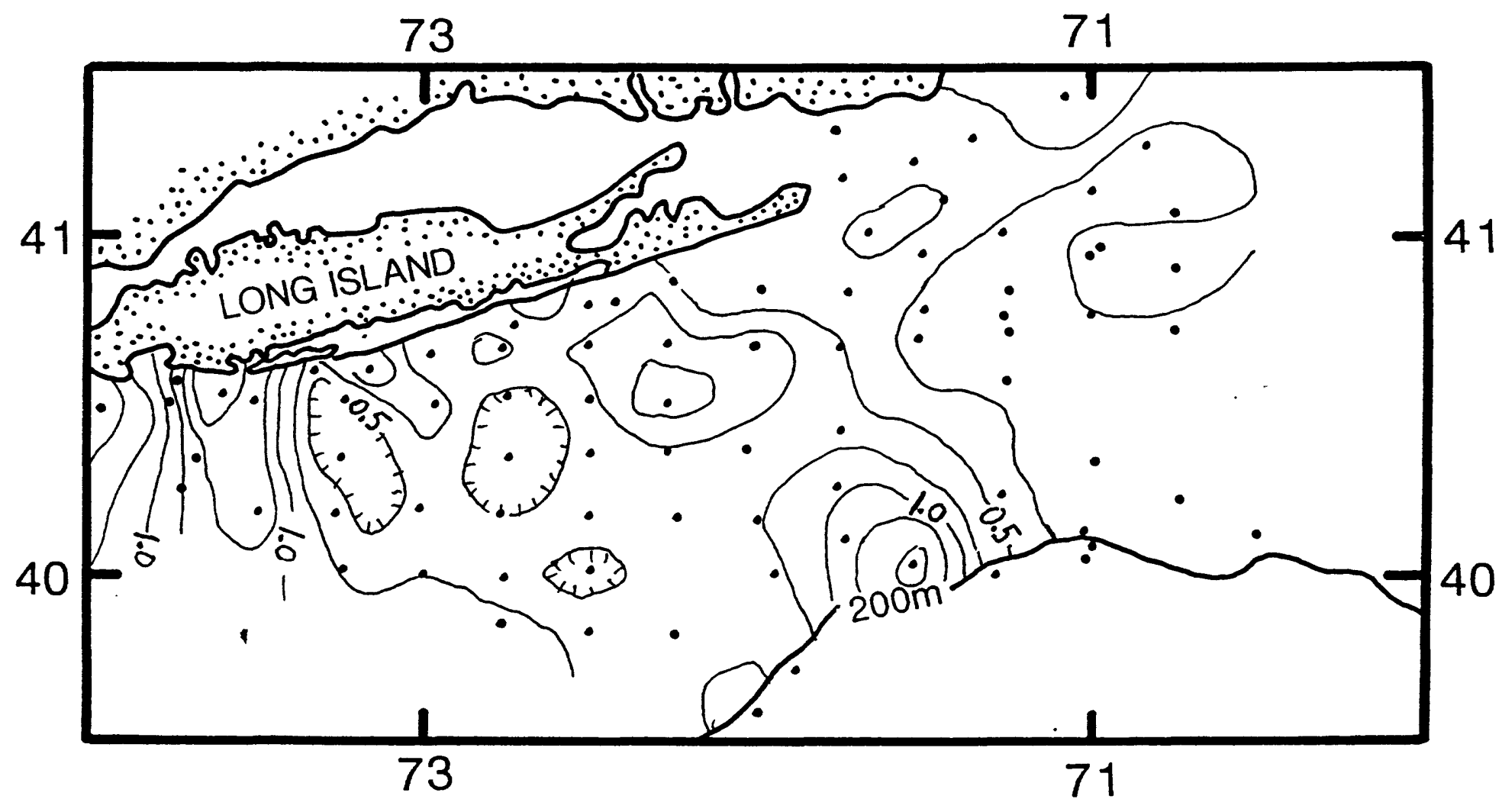

Figure 8.--Contour plot showing the percentage of economic heavy minerals (bulk sample basis) in the study area. Contour interval 0.25 percent. 


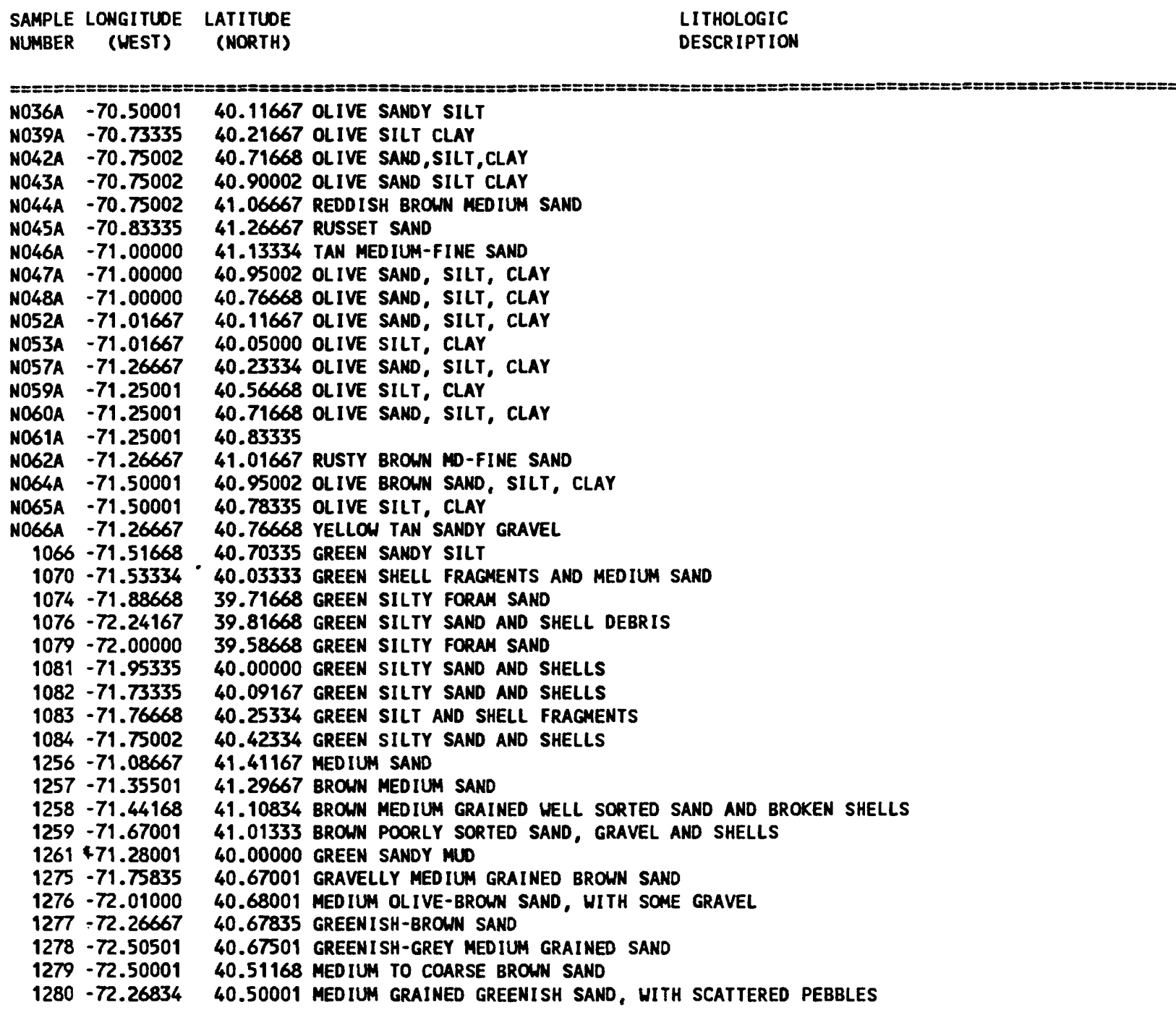

Table 1.--Location coordinates and lithologic descriptions of the surface grab samples. 


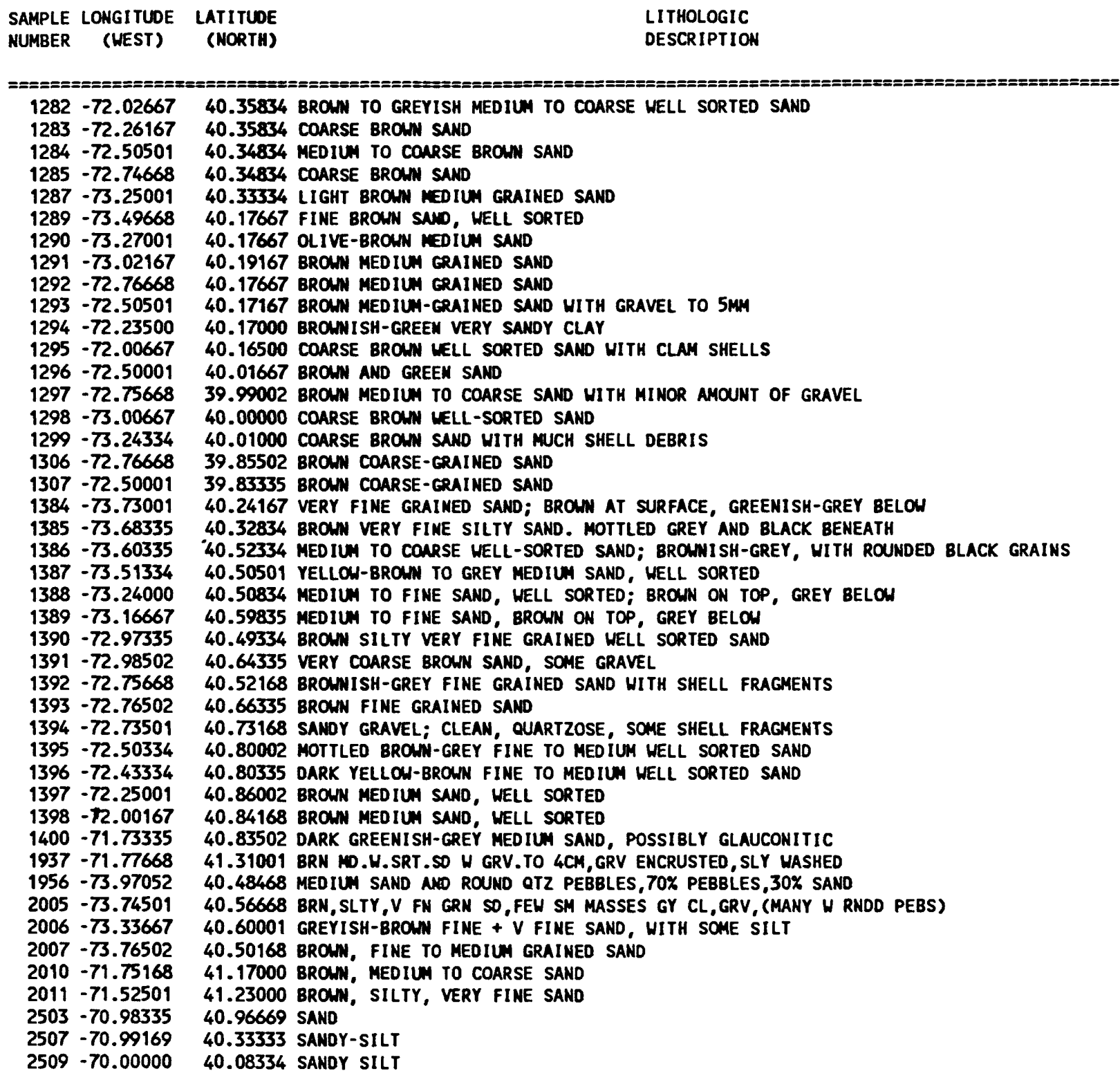

Table 1.--Continued. 
WATER GRAVEL WT $X$ WT $X$ WT $*$ WT MEAN GAMHA WT. $X$ SAMPLE DEPTH $>2.00>16<16->32<325 \%$ SIZE ACTIVITY $\mathrm{CaCO3}$ NUMBER (m) $\mathbb{X}$ MESH MESH MESH HM

SAND

\begin{tabular}{|c|c|c|c|c|c|c|c|c|c|}
\hline N036A & 129 & 0.0 & 3.7 & 88.1 & 8.2 & 0.24 & 0.12 & 1.22 & 8.03 \\
\hline N039A & 129 & 0.0 & 0.6 & 73.8 & 25.6 & 0.09 & 0.02 & ND & 8.84 \\
\hline N042A & 60 & 0.0 & 0.0 & 77.8 & 22.2 & 0.70 & 0.04 & ND & 0.51 \\
\hline N043A & 53 & 0.0 & 0.1 & 94.4 & 5.6 & 1.28 & 0.13 & ND & 0.88 \\
\hline N044A & 46 & 0.0 & 1.4 & 98.4 & 0.2 & 1.09 & 0.36 & ND & 0.21 \\
\hline N045A & 33 & 0.0 & 2.9 & 97.0 & 0.1 & 0.73 & 0.48 & ND & 0.21 \\
\hline N046A & 46 & 0.0 & 1.3 & 98.6 & 0.1 & 0.85 & 0.32 & 0.59 & 0.42 \\
\hline N047A & 59 & 0.0 & 3.9 & 92.3 & 3.8 & 0.97 & 0.10 & NO & ND \\
\hline N048A & 60 & 0.0 & 0.0 & 91.6 & 8.4 & 0.97 & 0.12 & 2.45 & 0.56 \\
\hline N052A & 165 & 1.0 & 4.0 & 88.9 & 7.1 & 1.21 & 0.09 & 1.95 & 9.81 \\
\hline N053A & 190 & 0.0 & 0.3 & 85.8 & 13.8 & 0.48 & 0.01 & ND & 12.07 \\
\hline N057A & 98 & 0.0 & 0.5 & 81.8 & 17.7 & 1.35 & 0.07 & ND & 2.30 \\
\hline N059A & 69 & 0.0 & 0.0 & 71.6 & 28.4 & 0.72 & 0.07 & ND & 0.69 \\
\hline MO6OA & 62 & 0.0 & 0.5 & 92.2 & 7.3 & 0.67 & 0.10 & ND & 0.72 \\
\hline N061A & 62 & 0.0 & 52.6 & 47.2 & 0.2 & 2.19 & 0.09 & ND & 0.36 \\
\hline M062A & 47 & 0.0 & 54.1 & 45.9 & 0.1 & 0.54 & 0.31 & ND & 6.55 \\
\hline N064A' & 57 & 0.0 & 0.7 & 95.9 & 3.4 & 1.31 & 0.14 & ND & 0.65 \\
\hline N065A & 62 & 0.0 & 0.2 & 85.7 & 14.1 & 0.76 & 0.05 & ND & 0.83 \\
\hline N066A & 60 & 26.0 & 49.6 & 50.3 & 0.0 & 0.29 & 1.19 & ND & 0.13 \\
\hline 1066 & 68 & 0.0 & 1.4 & 91.3 & 7.3 & 1.04 & 0.12 & 1.08 & 1.12 \\
\hline 1070 & 94 & 0.0 & 5.3 & 92.8 & 1.9 & 6.43 & 0.47 & 1.72 & 2.37 \\
\hline 1074 & 225 & 0.0 & 0.4 & 93.5 & 6.1 & 2.84 & 0.13 & 1.05 & 8.68 \\
\hline 1076 & 89 & 13.4 & 3.2 & 92.5 & 4.3 & 3.66 & 0.34 & ND & 1.92 \\
\hline 1079 & 292 & 0.0 & 1.1 & 90.6 & 8.3 & 2.35 & 0.09 & NO & 7.53 \\
\hline 1081 & 88 & 0.0 & 3.4 & 91.6 & 4.9 & 3.38 & 0.27 & 0.77 & 2.54 \\
\hline 1082 & 86 & 0.0 & 5.7 & 91.5 & 2.8 & 3.99 & 0.32 & ND & 1.94 \\
\hline 1083 & 82 & 0.0 & 2.4 & 88.2 & 9.4 & 3.91 & 0.08 & 1.34 & 1.56 \\
\hline 1084 & 76 & 0.0 & 4.8 & 89.6 & 5.6 & 2.62 & 0.13 & ND & 1.87 \\
\hline 1256 & 23 & 0.0 & 0.1 & 99.4 & 0.5 & 2.52 & 0.19 & 2.44 & 0.34 \\
\hline 1257 & 35 & 0.0 & 1.9 & 97.9 & 0.2 & 1.07 & 0.30 & ND & 0.78 \\
\hline 1258 & 38 & 0.0 & 1.4 & 97.9 & 0.7 & 1.75 & 0.15 & 1.36 & 1.15 \\
\hline 1259 & 45 & 0.0 & 11.9 & 86.8 & 1.4 & 2.60 & 0.16 & ND & 2.92 \\
\hline 1261 & 235 & 0.0 & 0.5 & 93.5 & 6.0 & 2.28 & 0.10 & ND & 8.62 \\
\hline 1275 & 59 & 29.5 & 30.3 & 68.9 & 0.8 & 2.19 & 1.05 & ND & 1.21 \\
\hline 1276 & 51 & 0.0 & 3.1 & 96.2 & 0.7 & 4.57 & 0.27 & ND & 1.07 \\
\hline 1277 & 53 & 0.0 & 0.7 & 98.2 & 1.1 & 2.75 & 0.16 & ND & 1.41 \\
\hline 1278 & 38 & 0.0 & 0.2 & 99.0 & 0.9 & 2.76 & 0.19 & ND & 1.04 \\
\hline 1279 & 44 & 0.0 & 4.5 & 95.3 & 0.2 & 4.53 & 0.41 & 0.79 & 1.26 \\
\hline 1280 & 49 & 0.0 & 3.9 & 94.5 & 1.7 & 5.62 & 0.21 & ND & 1.38 \\
\hline
\end{tabular}

Table 2.--Water depth, textural, carbonate content, and gamma radiation activity data for the surface grab samples. 
WATER GRAVEL WT $X$ WT $X$ WT $X$ HT MEAN GAMMA HT. $X$ SAMPLE DEPTH $>2.00>16<16->32<325 \times$ SIZE ACTIVITY CaCO3 NUMBER $(m) \quad m m$ MESH MESH MESH HM m CPM/g OF

SAND

\begin{tabular}{|c|c|c|c|c|c|c|c|c|c|}
\hline 1282 & 57 & 5.0 & 9.2 & 89.7 & 1.1 & 4.87 & 0.54 & ND & 2.26 \\
\hline 1283 & 61 & 22.3 & 8.8 & 90.7 & 0.5 & $2 . \pi 5$ & 0.66 & ND & 0.44 \\
\hline 1284 & 52 & 0.0 & 4.8 & 94.9 & 0.3 & 3.30 & 0.42 & MD & 3.06 \\
\hline 1285 & 52 & 0.0 & 12.8 & 87.0 & 0.2 & 1.22 & 0.31 & ND & 6.62 \\
\hline 1287 & 36 & 0.0 & 2.1 & 97.8 & 0.1 & 0.78 & 0.27 & ND & $1 . \pi 5$ \\
\hline 1289 & 38 & 0.0 & 0.2 & 99.7 & 0.2 & 6.32 & 0.14 & 2.37 & 0.80 \\
\hline 1290 & 40 & 0.0 & 2.9 & 96.9 & 0.2 & 1.55 & 0.36 & ND & 1.58 \\
\hline 1291 & 47 & 0.0 & 4.2 & 95.6 & 0.2 & 2.61 & 0.41 & 0.60 & 2.24 \\
\hline 1292 & 55 & 0.0 & 7.6 & 92.3 & 0.1 & $2 . \pi 5$ & 0.45 & ND & 3.78 \\
\hline 1293 & 64 & 17.3 & 16.8 & 82.5 & 0.8 & 2.82 & 0.58 & 1.15 & 7.27 \\
\hline 1294 & 70 & 0.0 & 5.6 & 89.8 & 4.6 & 2.53 & 0.29 & ND & 4.98 \\
\hline 1295 & 67 & 0.0 & 3.3 & 96.4 & 0.2 & 4.47 & 0.40 & 0.78 & 1.78 \\
\hline 1296 & 69 & 0.0 & 0.7 & 95.8 & 3.5 & 2.45 & 0.26 & ND & 0.98 \\
\hline 1297 & 56 & 0.0 & 12.9 & 86.8 & 0.4 & 3.45 & 0.55 & ND & 5.04 \\
\hline 1298 & 51 & 0.0 & 7.1 & 92.7 & 0.2 & 3.62 & 0.46 & ND & 1.21 \\
\hline 1299 & 50 & 0.0 & 12.9 & 86.3 & 0.7 & 2.66 & 0.30 & ND & 6.92 \\
\hline 1306 & 55 & 0.0 & 5.3 & 94.6 & 0.1 & 4.84 & 0.40 & ND & 2.52 \\
\hline 1307 & 64 & 0.0 & 4.2 & 95.7 & 0.1 & 4.56 & 0.41 & 0.94 & 1.04 \\
\hline 1384 & 37 & 0.0 & 0.1 & 99.6 & 0.3 & 3.27 & 0.12 & ND & 0.72 \\
\hline 1385 & 28 & 0.0 & 0.7 & 98.5 & 0.8 & 5.35 & 0.14 & 2.20 & 1.10 \\
\hline 1386 & 21 & 0.0 & 0.1 & 99.8 & 0.1 & 5.34 & 0.19 & 1.61 & 0.95 \\
\hline 1387 & 20 & 0.0 & 0.5 & 99.4 & 0.1 & 5.12 & 0.21 & ND & 0.90 \\
\hline 1388 & 30 & 0.0 & 0.4 & 99.5 & 0.2 & 0.70 & 0.39 & 0.48 & 1.68 \\
\hline 1389 & 22 & 0.0 & 0.2 & 99.8 & 0.0 & 4.16 & 0.21 & ND & 1.10 \\
\hline 1390 & 40 & 0.0 & 0.2 & 99.2 & 0.6 & 3.40 & 0.16 & 1.75 & 1.04 \\
\hline 1391 & 21 & 10.0 & 17.7 & 82.3 & 0.0 & 1.21 & 0.60 & 0.29 & 1.47 \\
\hline 1392 & 40 & 0.0 & 4.6 & 95.2 & 0.1 & 1.55 & 0.33 & ND & 1.39 \\
\hline 1393 & 31 & 0.0 & 0.2 & 99.6 & 0.2 & 3.96 & 0.16 & ND & 0.86 \\
\hline 1394 & 23 & 45.4 & 48.5 & 51.4 & 0.1 & 2.41 & 0.68 & 0.82 & 0.88 \\
\hline 1395 & 23 & 0.0 & 0.7 & 99.3 & 0.0 & 1.51 & 0.46 & ND & 1.65 \\
\hline 1396 & 28 & 0.0 & 0.3 & 99.3 & 0.4 & 4.51 & 0.17 & 2.40 & 0.72 \\
\hline 1397 & 30 & 0.0 & 0.7 & 99.2 & 0.2 & 2.30 & 0.28 & ND & 0.73 \\
\hline 1398 & 39 & 0.0 & 0.9 & 98.9 & 0.3 & 2.06 & 0.30 & 1.12 & 2.11 \\
\hline 1400 & 54 & 3.0 & 9.3 & 89.6 & 1.1 & 2.08 & 0.24 & 2.16 & 1.47 \\
\hline 1937 & 16 & 29.2 & 46.6 & 51.8 & 1.7 & 4.03 & 0.82 & 2.64 & 0.62 \\
\hline 1956 & 9 & 5.0 & 76.3 & 23.5 & 0.2 & 0.29 & 0.38 & 0.32 & 2.10 \\
\hline 2005 & 13 & 0.0 & 2.7 & 96.5 & 0.9 & 6.84 & 0.15 & 3.01 & 0.62 \\
\hline 2006 & 14 & 0.0 & 0.1 & 99.9 & 0.0 & 3.24 & 0.18 & 1.48 & 0.21 \\
\hline 2007 & 24 & 0.0 & 0.3 & 99.6 & 0.1 & 9.24 & 0.21 & ND & 0.16 \\
\hline 2010 & 23 & 0.0 & 0.1 & 99.6 & 0.3 & 0.72 & 0.32 & 0.47 & 0.20 \\
\hline 2011 & 34 & 0.0 & 0.0 & 98.9 & 1.1 & 1.63 & 0.13 & ND & 0.21 \\
\hline 2503 & 49 & ND & 1.6 & 97.6 & 0.8 & 1.27 & ND & ND & ND \\
\hline 2507 & 93 & 0.0 & 0.8 & 76.4 & 22.8 & 0.25 & 0.03 & ND & ND \\
\hline 2509 & 188 & ND & 0.8 & 79.8 & 19.4 & 0.82 & ND & ND & ND \\
\hline COUNT & 83 & 81 & 83 & 83 & 83 & 83 & 81 & 31 & 79 \\
\hline MINIMUM & 9 & 0.0 & 0.0 & 23.5 & 0.0 & 0.09 & 0.01 & 0.29 & 0.13 \\
\hline AVERAGE & 63 & 2.6 & 7.2 & 89.2 & 3.6 & 2.58 & 0.28 & 1.40 & 2.30 \\
\hline MAXIMUM & 292 & 45.4 & 76.3 & 99.9 & 28.4 & 9.24 & 1.19 & 3.01 & 12.07 \\
\hline S.D. & 50 & 7.9 & 14.4 & 14.4 & 6.2 & 1.80 & 0.21 & 0.75 & 2.64 \\
\hline
\end{tabular}

Table 2.--Continued. 
POTASH PLAGIOCLASE TOTAL

SAMPLE FELDSPAR FELDSPAR FELDSPAR

NUMBER AS A PERCENTAGE OF THE MONCARBONATE $0.125-.250 \mathrm{~mm}$ FRACTION

\begin{tabular}{|c|c|c|c|c|c|c|c|c|c|c|}
\hline N036A & & 6 & 3 & 9 & 1.0 & $N$ & 25.0 & 7.0 & 20.0 & 15.0 \\
\hline N039A & & 16 & 4 & 20 & 5.0 & N & 30.0 & 15.0 & 15.0 & 10.0 \\
\hline N042A & & 7 & 17 & 24 & N & $N$ & 18.0 & 5.0 & 5.0 & 16.0 \\
\hline N043A & & 24 & 0 & 24 & 1.0 & $N$ & 23.0 & 10.0 & 10.0 & 8.0 \\
\hline N044A & & 0 & 4 & 4 & N & N & 15.0 & 7.0 & 7.0 & 10.0 \\
\hline N045A & & 3 & 0 & 3 & 2.0 & 1.0 & 10.0 & 6.0 & 6.0 & 10.0 \\
\hline N046A & & 5 & 0 & 5 & 4.0 & N & 5.0 & 5.0 & 5.0 & 5.0 \\
\hline N047A & & 3 & 0 & 3 & 2.0 & N & 20.0 & 5.0 & 5.0 & 17.0 \\
\hline N048A & & 0 & 0 & 0 & 1.0 & $N$ & 10.0 & 6.0 & 6.0 & 20.0 \\
\hline N052A & & 0 & 8 & 8 & 1.0 & 1.0 & 18.0 & 3.0 & 3.0 & 36.0 \\
\hline N053A & & 31 & 0 & 31 & 1.0 & N & 5.0 & 4.0 & 4.0 & 23.0 \\
\hline N057A & & 8 & 0 & 8 & 1.0 & 1.0 & 20.0 & 3.0 & 3.0 & 30.0 \\
\hline N059A & & 0 & 9 & 9 & 5.0 & 1.0 & 15.0 & 4.0 & 4.0 & 30.0 \\
\hline N060A & & 0 & 12 & 12 & 3.0 & N & 7.0 & 4.0 & 4.0 & 25.0 \\
\hline N061A & & 0 & 7 & 7 & 1.0 & 0.1 & 4.9 & 0.8 & 0.8 & 2.5 \\
\hline N062A & & 0 & 5 & 5 & 5.0 & 5.0 & 2.0 & 1.0 & 1.0 & 27.0 \\
\hline N064A & & 6 & 5 & 11 & 5.0 & 5.0 & 25.0 & 6.0 & 6.0 & 20.0 \\
\hline N065A & & 8 & 0 & 8 & 5.0 & N & 10.0 & 6.0 & 6.0 & 25.0 \\
\hline N066A & & 0 & 4 & 4 & 3.0 & N & 20.0 & 6.0 & 6.0 & 25.0 \\
\hline 1066 & & 40 & 0 & 40 & 1.0 & N & 9.0 & 5.0 & 5.0 & 60.0 \\
\hline 1070 & & 3 & 10 & 13 & 21.7 & 7.2 & 28.8 & 5.7 & 5.7 & 15.1 \\
\hline 1074 & & 5 & 2 & 7 & 4.2 & 5.1 & 22.9 & 5.2 & 5.2 & 28.8 \\
\hline 1076 & & 8 & 4 & 12 & 7.1 & 4.4 & 33.2 & 11.1 & 11.1 & 19.5 \\
\hline 1079 & & 3 & 4 & 7 & 5.0 & 10.0 & 10.0 & 5.0 & 5.0 & 41.0 \\
\hline 1081 & & 11 & 16 & 27 & 4.7 & 1.8 & 38.3 & 6.3 & 6.3 & 20.7 \\
\hline 1082 & & 0 & 7 & 7 & 4.5 & 0.7 & 38.0 & 4.4 & 4.4 & 15.9 \\
\hline 1083 & 1 & 0 & 15 & 15 & 5.6 & 1.6 & 23.1 & 4.2 & 4.2 & 31.9 \\
\hline 1084 & & 5 & 8 & 13 & 4.2 & 1.7 & 23.7 & 3.4 & 3.4 & 33.8 \\
\hline 1256 & & 3 & 0 & 3 & 10.5 & 3.6 & 10.2 & 3.0 & 3.0 & 22.7 \\
\hline 1257 & & 2 & 2 & 4 & 4.7 & 3.3 & 3.8 & 3.2 & 3.2 & 21.4 \\
\hline 1258 & & 4 & 9 & 13 & 5.1 & 2.7 & 6.5 & 1.8 & 1.8 & 22.9 \\
\hline 1259 & & 18 & 1 & 19 & 7.0 & 7.7 & 12.4 & 6.6 & 6.6 & 26.8 \\
\hline 1261 & & 13 & 0 & 13 & 6.7 & 3.0 & 22.1 & 3.7 & 3.7 & 35.0 \\
\hline $12 \pi 5$ & & 6 & 2 & 8 & 3.4 & 3.6 & 32.1 & 7.3 & 7.3 & 18.6 \\
\hline 1276 & & 5 & 16 & 21 & 5.2 & 2.8 & 34.5 & 10.9 & 10.9 & 19.1 \\
\hline 1277 & & 16 & 0 & 16 & 3.3 & 0.6 & 10.9 & 3.3 & 3.3 & 35.3 \\
\hline 1278 & & 6 & 0 & 6 & 5.2 & 1.3 & 11.3 & 8.2 & 8.2 & 29.2 \\
\hline 1279 & & 8 & 0 & 8 & 4.5 & 0.8 & 35.3 & 11.9 & 11.9 & 16.0 \\
\hline 1280 & & 0 & 26 & 26 & 3.1 & 2.3 & 17.3 & 5.3 & 5.3 & 32.0 \\
\hline
\end{tabular}

Table 3.--Feldspar and heavy-mineral data for the surface grab samples. 
POtASH PLAGIOCLASE TOTAL

SAMPLE FELDSPAR FELDSPAR FELDSPAR

MUMBER AS A PERCENTAGE OF THE NONCARBONATE $0.125-.250 \mathrm{~mm}$ FRACTION

ILMENITE MAGNETITE gARNET STAUROLITE EPIDOTE PYROBOLES

\begin{tabular}{|c|c|c|c|c|c|c|c|c|c|}
\hline 1282 & 3 & 14 & 17 & 4.3 & 0.6 & 37.8 & 7.3 & 7.3 & 26.7 \\
\hline 1283 & 5 & 0 & 5 & 2.1 & 0.7 & 26.3 & 11.1 & 11.1 & 22.3 \\
\hline 1284 & 3 & 5 & 8 & 3.2 & 0.5 & 34.0 & 9.6 & 9.6 & 17.4 \\
\hline 1285 & 3 & 0 & 3 & 1.0 & 1.0 & 15.0 & 6.0 & 6.0 & 22.0 \\
\hline 1287 & 0 & 0 & 0 & 0.0 & 1.0 & 16.0 & 10.0 & 10.0 & 19.0 \\
\hline 1289 & 8 & 12 & 20 & 3.2 & 0.8 & 13.5 & 2.4 & 2.4 & 38.5 \\
\hline 1290 & 2 & 5 & 7 & 5.4 & 1.2 & 27.1 & 6.6 & 6.6 & 21.6 \\
\hline 1291 & 7 & 0 & 7 & 11.2 & 3.2 & 32.7 & 8.5 & 8.5 & 17.9 \\
\hline 1292 & 6 & 0 & 6 & 9.4 & 5.7 & 29.4 & 5.6 & 5.6 & 21.3 \\
\hline 1293 & 16 & 0 & 16 & 8.4 & 3.4 & 20.5 & 4.2 & 4.2 & 32.0 \\
\hline 1294 & 0 & 21 & 21 & 2.6 & 1.7 & 12.5 & 1.6 & 1.6 & 37.5 \\
\hline 1295 & 3 & 6 & 9 & 4.0 & 0.4 & 43.5 & 4.2 & 4.2 & 18.2 \\
\hline 1296 & 6 & 7 & 13 & 5.1 & 6.7 & 24.5 & 4.5 & 4.5 & 26.9 \\
\hline 1297 & 5 & 10 & 15 & 7.0 & 9.2 & 26.6 & 10.3 & 10.3 & 26.8 \\
\hline 1298 & 10 & 0 & 10 & 8.3 & 11.6 & 19.1 & 8.0 & 8.0 & 26.2 \\
\hline 1299 & 13 & 0 & 13 & 4.5 & 9.0 & 18.1 & 7.3 & 7.3 & 29.9 \\
\hline 1306 & $9^{\circ}$ & 13 & 22 & 6.1 & 15.7 & 14.2 & 10.3 & 10.3 & 21.6 \\
\hline 1307 & 8 & 3 & 11 & 6.8 & 8.8 & 19.7 & 7.2 & 7.2 & 23.1 \\
\hline 1384 & 4 & 6 & 10 & 1.4 & 4.7 & 17.0 & 3.5 & 3.5 & 24.3 \\
\hline 1385 & 10 & 0 & 10 & 5.0 & 5.2 & 15.6 & 4.2 & 4.2 & 23.2 \\
\hline 1386 & 0 & 4 & 4 & 5.8 & 5.4 & 4.4 & 1.7 & 1.7 & 25.1 \\
\hline 1387 & 0 & 0 & 0 & 4.6 & 1.1 & 20.2 & 10.8 & 10.8 & 19.9 \\
\hline 1388 & 0 & 0 & 0 & 5.0 & 5.0 & 25.0 & 7.0 & 7.0 & 28.0 \\
\hline 1389 & 5 & 7 & 12 & 3.2 & 1.1 & 16.9 & 8.2 & 8.2 & 20.0 \\
\hline 1390 & 0 & 6 & 6 & 3.0 & 2.2 & 17.0 & 4.7 & 4.7 & 26.4 \\
\hline 1391 & 0 & 0 & 0 & 1.0 & 0.5 & 17.5 & 14.7 & 14.7 & 12.5 \\
\hline 1392 & 0 & 8 & 8 & 2.7 & 0.4 & 27.2 & 12.9 & 12.9 & 15.0 \\
\hline 1393 & 7 & 0 & 7 & 2.7 & 0.9 & 14.9 & 5.1 & 5.1 & 28.5 \\
\hline 1394 & 0 & 0 & 0 & 4.1 & 0.3 & 31.4 & 12.5 & 12.5 & 17.9 \\
\hline 1395 & 0 & 0 & 0 & 3.9 & 0.6 & 16.8 & 12.2 & 12.2 & 18.8 \\
\hline 1396 & 5 & 19 & 24 & 1.6 & 3.2 & 17.1 & 3.9 & 3.9 & 25.9 \\
\hline 1397 & 4 & 16 & 20 & 5.9 & 4.9 & 27.5 & 2.8 & 2.8 & 22.0 \\
\hline 1398 & 2 & 8 & 10 & 3.0 & 1.9 & 23.9 & 3.8 & 3.8 & 28.2 \\
\hline 1400 & 6 & 1 & 7 & 1.0 & 10.0 & 8.0 & 3.0 & 3.0 & 41.0 \\
\hline 1937 & 21 & 21 & 42 & 9.6 & 10.2 & 7.1 & 1.0 & 1.0 & 46.1 \\
\hline 1956 & 0 & 11 & 11 & 2.0 & 10.0 & 5.0 & 2.0 & 2.0 & 40.0 \\
\hline 2005 & 2 & 13 & 15 & 3.4 & 1.5 & 15.9 & 2.3 & 2.3 & 35.3 \\
\hline 2006 & 10 & 0 & 10 & 1.1 & 1.7 & 24.9 & 6.9 & 6.9 & 24.8 \\
\hline 2007 & 11 & 0 & 11 & 2.9 & 5.9 & 8.0 & 1.2 & 1.2 & 27.9 \\
\hline 2010 & 0 & 15 & 15 & 2.0 & 8.0 & 35.0 & 2.0 & 2.0 & 30.0 \\
\hline 2011 & 19 & 0 & 19 & 8.9 & 12.7 & 13.0 & 1.4 & 1.4 & 20.8 \\
\hline 2503 & ND & ND & ND & 8.6 & 1.7 & 14.0 & 4.8 & 4.8 & 11.9 \\
\hline 2507 & ND & ND & ND & 7.0 & $N$ & 38.0 & 5.0 & 5.0 & 10.0 \\
\hline 2509 & ND & ND & ND & 2.0 & 1.0 & 30.0 & 4.0 & 4.0 & 15.0 \\
\hline COUNT & 80 & 80 & 80 & 81 & 69 & 83 & 83 & 83 & 83 \\
\hline MINIMUM & 0 & 0 & 0 & 0.0 & 0.1 & 2.0 & 0.8 & 0.8 & 2.5 \\
\hline AVERAGE & 6 & 5 & 11 & 4.4 & 3.8 & 19.6 & 5.9 & 6.0 & 23.9 \\
\hline MAXIMUM & 40 & 26 & 42 & 21.7 & 15.7 & 43.5 & 15.0 & 20.0 & 60.0 \\
\hline S.D. & 7 & 6 & 8 & 3.1 & 3.5 & 9.8 & 3.3 & 3.6 & 9.3 \\
\hline
\end{tabular}

Table 3.--Continued. 
SAMPLE

NUMBER ALUMINO- TOURMALINE LEUCOXENE RUTILE ZIRCON MONAZITE SPHENE OTHERS HT $x$ UT $\times$ SILICATES EHM/C EHM/T

\begin{tabular}{|c|c|c|c|c|c|c|c|c|c|c|c|}
\hline N036A & & 10.0 & 12.0 & $\mathbf{N}$ & 1.0 & 4.0 & $\mathbf{N}$ & 1.0 & 4.0 & 16.0 & 0.04 \\
\hline N039A & & 5.0 & 20.0 & $\mathbf{N}$ & 1.0 & 1.0 & $\mathbf{N}$ & 1.0 & 7.0 & 12.0 & 0.01 \\
\hline N042A & & 15.0 & 20.0 & N & 3.0 & 6.0 & $N$ & $N$ & 2.0 & 24.0 & 0.17 \\
\hline N043A & & 15.0 & 20.0 & N & 2.0 & 10.0 & N & 1.0 & 3.0 & 28.0 & 0.36 \\
\hline N044A & & 8.0 & 22.0 & 4.0 & 3.0 & 7.0 & 1.0 & 2.0 & 16.0 & 23.0 & 0.25 \\
\hline N045A & & 5.0 & 38.0 & 1.0 & 1.0 & 3.0 & N & 2.0 & 20.0 & 12.0 & 0.09 \\
\hline N046A & & 10.0 & 38.0 & 2.0 & 1.0 & 3.0 & $\mathbf{N}$ & 5.0 & 19.0 & 20.0 & 0.17 \\
\hline N047A & & 20.0 & 15.0 & 1.0 & $N$ & 13.0 & $\mathbf{N}$ & N & 2.0 & 36.0 & 0.35 \\
\hline NO48A & & 15.0 & 20.0 & N & 1.0 & 7.0 & $N$ & 2.0 & 3.0 & 24.0 & 0.23 \\
\hline N052A & & 15.0 & 12.0 & N & 1.0 & 4.0 & $\mathbf{N}$ & 1.0 & 1.0 & 21.0 & 0.25 \\
\hline N053A & & 38.0 & 18.0 & N & $N$ & 5.0 & N & N & 2.0 & 44.0 & 0.21 \\
\hline N057A & & 17.0 & 15.0 & N & 1.0 & 4.0 & $N$ & 1.0 & 2.0 & 23.0 & 0.31 \\
\hline N059A & & 28.0 & 7.0 & $N$ & 1.0 & 3.0 & N & 1.0 & 2.0 & 37.0 & 0.27 \\
\hline N060A & & 29.0 & 15.0 & 1.0 & 1.0 & 9.0 & N & 1.0 & 2.0 & 43.0 & 0.29 \\
\hline N061A & & 1.7 & 1.7 & $N$ & 0.3 & 0.2 & $N$ & 0.2 & 86.5 & 3.2 & 0.07 \\
\hline N062A & & 10.0 & 5.0 & N & 1.0 & 2.0 & $\mathbf{N}$ & 1.0 & 40.0 & 18.0 & 0.10 \\
\hline N064A & & 15.0 & 15.0 & N & 1.0 & 1.0 & $\mathbf{N}$ & 1.0 & 2.0 & 22.0 & 0.29 \\
\hline N065A & & 24.0 & 17.0 & $N$ & 1.0 & 3.0 & N & 1.0 & 2.0 & 33.0 & 0.25 \\
\hline N066A & & 15.0 & 5.0 & $\mathbf{N}$ & $\mathbf{N}$ & $\mathbf{N}$ & $\mathbf{N}$ & $\mathbf{N}$ & 25.0 & 18.0 & 0.05 \\
\hline 1066 & & 7.0 & 4.0 & N & $\mathbf{N}$ & 1.0 & $\mathbf{N}$ & 3.0 & 5.0 & 9.0 & 0.09 \\
\hline 1070 & & 5.4 & 2.3 & 0.4 & 0.5 & 0.9 & $N$ & 0.6 & 3.9 & 28.9 & 1.86 \\
\hline 1074 & & 12.7 & 1.5 & 0.6 & 0.8 & 2.1 & $\mathbf{N}$ & 0.4 & 2.7 & 20.5 & 0.58 \\
\hline 1076 & & 7.0 & 3.9 & 0.3 & 0.6 & 0.6 & N & 0.3 & 4.8 & 15.7 & 0.57 \\
\hline 1079 & & 10.0 & 5.0 & N & 1.0 & 2.0 & $N$ & 1.0 & 5.0 & 18.0 & 0.42 \\
\hline 1081 & & 10.3 & 3.6 & 0.9 & 0.8 & 1.4 & $\mathbf{N}$ & 0.4 & 4.4 & 18.1 & 0.61 \\
\hline 1082 & & 21.0 & 4.6 & 0.1 & 0.8 & 0.5 & N & 0.3 & 2.3 & 27.0 & 1.08 \\
\hline 1083 & । & 19.3 & 1.6 & 0.3 & 1.2 & 0.9 & $M$ & 0.4 & 2.6 & 27.4 & 1.07 \\
\hline 1084 & & 13.3 & 3.6 & 0.3 & 2.1 & 1.1 & $\mathbf{N}$ & 0.6 & 5.1 & 21.1 & 0.55 \\
\hline 1256 & & 19.8 & 7.9 & N & 2.5 & 4.6 & $\mathbf{N}$ & 0.8 & 8.8 & 37.4 & 0.94 \\
\hline 1257 & & 16.3 & 6.2 & 0.7 & 1.0 & 2.8 & 0.1 & 1.0 & 29.0 & 25.6 & 0.27 \\
\hline 1258 & & 25.6 & 7.5 & 1.8 & 3.1 & 4.4 & $\mathbf{N}$ & 2.2 & 13.3 & 40.0 & 0.70 \\
\hline 1259 & & 15.8 & 3.1 & $\mathbf{N}$ & 1.9 & 3.4 & $\mathbf{N}$ & 1.9 & 8.4 & 28.1 & 0.73 \\
\hline 1261 & & 12.2 & 3.3 & N & 2.5 & 2.5 & N & 0.9 & 3.1 & 23.9 & 0.54 \\
\hline 1275 & & 18.3 & 4.5 & 2.6 & 1.3 & 1.0 & $\mathbf{N}$ & 1.7 & 3.7 & 26.6 & 0.58 \\
\hline 1276 & & 13.2 & 3.4 & 1.0 & 0.6 & 1.5 & $\mathbf{N}$ & 0.7 & 4.7 & 21.5 & 0.98 \\
\hline 1277 & & 19.3 & 5.6 & 1.6 & 1.7 & 2.4 & $N$ & 2.2 & 7.2 & 28.4 & 0.78 \\
\hline 1278 & & 17.7 & 9.5 & 1.3 & 2.0 & 2.8 & $\mathbf{N}$ & 1.4 & 5.3 & 28.9 & 0.80 \\
\hline 1279 & & 7.6 & 11.1 & $\mathbf{N}$ & 2.0 & 1.2 & $\mathbf{N}$ & 1.5 & 1.6 & 15.2 & 0.69 \\
\hline 1280 & & 19.5 & 7.5 & 0.5 & 0.7 & 0.8 & $\mathbf{N}$ & 2.2 & 4.2 & 24.4 & 1.37 \\
\hline
\end{tabular}

Table 3.--Continued. 
SAMPLE

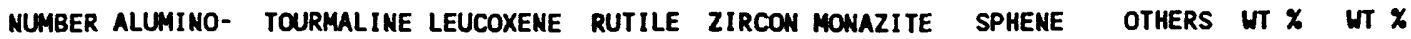
SILICATES

\begin{tabular}{|c|c|c|c|c|c|c|c|c|c|c|}
\hline 1282 & 5.8 & 8.2 & 0.3 & 1.0 & 0.5 & $N$ & 0.5 & 1.9 & 11.9 & 0.58 \\
\hline 1283 & 13.7 & 9.0 & $N$ & 2.4 & 0.9 & $N$ & 1.5 & 2.6 & 19.0 & 0.52 \\
\hline 1284 & 12.4 & 10.1 & $N$ & 1.3 & 1.5 & $N$ & 1.0 & 1.7 & 18.3 & 0.60 \\
\hline 1285 & 10.0 & 15.0 & 1.0 & 2.0 & 4.0 & $N$ & 3.0 & 5.0 & 18.0 & 0.22 \\
\hline 1287 & 15.0 & 15.0 & 1.0 & 4.0 & 3.0 & $N$ & 5.0 & 7.0 & 23.0 & 0.18 \\
\hline 1289 & 16.9 & 6.1 & 1.5 & 1.6 & 1.6 & $N$ & 1.5 & 3.0 & 24.8 & 1.57 \\
\hline 1290 & 16.6 & 7.3 & 0.6 & 0.8 & 2.3 & 0.4 & 2.2 & 3.2 & 26.1 & 0.40 \\
\hline 1291 & 7.0 & 8.1 & 1.0 & 0.9 & 1.7 & $N$ & 1.3 & 2.8 & 21.8 & 0.57 \\
\hline 1292 & 6.6 & 5.8 & 1.2 & 0.4 & 0.8 & $N$ & 1.5 & 3.4 & 18.4 & 0.51 \\
\hline 1293 & 11.7 & 5.5 & 3.5 & 1.3 & 0.9 & $N$ & 0.7 & 1.9 & 25.8 & 0.73 \\
\hline 1294 & 18.5 & 6.5 & 0.8 & 2.8 & 1.8 & $N$ & 0.1 & 2.1 & 26.4 & 0.67 \\
\hline 1295 & 10.4 & 6.3 & 1.4 & 0.6 & 0.4 & $M$ & 2.1 & 2.2 & 16.8 & 0.75 \\
\hline 1296 & 6.8 & 4.6 & 0.1 & 1.2 & 1.5 & $N$ & 0.7 & 4.8 & 14.7 & 0.36 \\
\hline 1297 & 4.7 & 3.1 & 1.5 & 0.3 & 0.7 & $N$ & 3.4 & 3.6 & 14.2 & 0.49 \\
\hline 1298 & 8.6 & 1.7 & 1.3 & 1.1 & 1.4 & $N$ & 3.0 & 5.4 & 20.6 & 0.75 \\
\hline 1299 & 15.4 & 1.8 & 1.1 & 0.5 & 2.0 & $N$ & 1.5 & 5.7 & 23.5 & 0.63 \\
\hline 1306 & 10.9 & 6.8 & 1.3 & 0.3 & 0.8 & $N$ & 1.9 & 9.4 & 19.5 & 0.94 \\
\hline 1307 & 6.4 & 1.7 & $N$ & 0.4 & 0.7 & $M$ & 1.0 & 24.0 & 14.3 & 0.65 \\
\hline 1384 & 22.1 & 5.3 & 2.4 & 1.3 & 3.3 & $N$ & 0.8 & 9.1 & 30.5 & 1.00 \\
\hline 1385 & 13.6 & 3.5 & 1.3 & 1.0 & 2.5 & $N$ & 0.8 & 21.5 & 23.4 & 1.25 \\
\hline 1386 & 34.1 & 3.4 & 1.6 & 4.7 & 0.5 & $M$ & $N$ & 9.8 & 46.6 & 2.49 \\
\hline 1387 & 15.7 & 7.7 & 1.4 & 1.7 & 2.6 & $N$ & 1.7 & 7.2 & 25.9 & 1.33 \\
\hline 1388 & 7.0 & 13.0 & $N$ & 2.0 & 2.0 & $N$ & 1.0 & 4.0 & 16.0 & 0.11 \\
\hline 1389 & 23.5 & 6.1 & 3.0 & 2.5 & 1.8 & $N$ & 1.1 & 6.2 & 33.9 & 1.41 \\
\hline 1390 & 24.5 & 4.0 & 1.6 & 0.9 & 0.9 & $N$ & 0.2 & 8.0 & 30.9 & 1.05 \\
\hline 1391 & 19.8 & 13.1 & 1.4 & 2.7 & 2.7 & $M$ & 0.7 & 5.8 & 27.5 & 0.33 \\
\hline 1392 & 8.3 & 13.4 & 0.7 & 2.2 & 1.8 & $N$ & 1.0 & 3.3 & 15.8 & 0.24 \\
\hline 1393 & 21.7 & 6.2 & 2.4 & 1.5 & 2.7 & $N$ & 0.8 & 5.6 & 31.2 & 1.24 \\
\hline 1394 & 10.6 & 9.4 & 0.7 & 1.8 & 2.1 & $N$ & N & 3.6 & 19.4 & 0.47 \\
\hline 1395 & 16.3 & 14.9 & 2.6 & 2.5 & 2.5 & $N$ & 0.6 & 3.3 & 27.7 & 0.42 \\
\hline 1396 & 22.4 & 6.5 & 3.4 & 1.4 & 2.2 & $N$ & 0.1 & 7.5 & 31.1 & 1.40 \\
\hline 1397 & 2.4 & 12.0 & 0.4 & 1.5 & $N$ & $N$ & 0.8 & 8.0 & 10.3 & 0.24 \\
\hline 1398 & 7.3 & 6.6 & 1.6 & 1.8 & 1.6 & $N$ & 1.2 & 4.3 & 15.4 & 0.32 \\
\hline 1400 & 5.0 & 5.0 & $N$ & 3.0 & 4.0 & $M$ & 2.0 & 15.0 & 13.0 & 0.27 \\
\hline 1937 & 3.0 & 1.2 & 0.5 & 0.2 & 0.5 & 0.2 & 0.7 & 7.8 & 14.1 & 0.57 \\
\hline 1956 & 5.0 & 5.0 & 2.0 & 2.0 & 2.0 & $M$ & 2.0 & 20.0 & 13.0 & 0.04 \\
\hline 2005 & 12.5 & 2.1 & 0.9 & 0.8 & $N$ & $N$ & 0.9 & 9.0 & 17.5 & 1.20 \\
\hline 2006 & 10.0 & 6.8 & 0.3 & 2.2 & 2.8 & $N$ & 0.4 & 5.2 & 16.4 & 0.53 \\
\hline 2007 & 2.3 & 0.7 & N & 0.1 & 0.6 & $N$ & 0.2 & 50.2 & 5.9 & 0.55 \\
\hline 2010 & 3.0 & 5.0 & $N$ & $N$ & 1.0 & $N$ & 3.0 & 5.0 & 6.0 & 0.04 \\
\hline 2011 & 9.4 & 3.7 & 0.2 & 0.9 & 2.2 & $N$ & $N$ & 11.0 & 21.7 & 0.35 \\
\hline 2503 & 10.0 & 8.7 & 0.7 & 2.3 & 2.8 & $N$ & 1.2 & 10.3 & 24.5 & 0.31 \\
\hline 2507 & 5.0 & 20.0 & $N$ & $M$ & 4.0 & $M$ & 1.0 & 3.0 & 16.0 & 0.04 \\
\hline 2509 & 8.0 & 15.0 & 1.0 & 1.0 & 5.0 & $N$ & 1.0 & 2.0 & 17.0 & 0.14 \\
\hline COUNT & 83 & 83 & 55 & $\pi$ & 80 & 4 & 76 & 83 & 83 & 83 \\
\hline MINIMU & 1.7 & 0.7 & 0.1 & 0.1 & 0.2 & 0.1 & 0.1 & 1.0 & 3.2 & 0.01 \\
\hline AVERAG & 13.3 & 8.9 & 1.3 & 1.5 & 2.5 & 0.4 & 1.3 & 8.4 & 22.3 & 0.57 \\
\hline MAXIMU & 38.0 & 38.0 & 4.0 & 4.7 & 13.0 & 1.0 & 5.0 & 86.5 & 46.6 & 2.49 \\
\hline S.D. & 7.3 & 7.1 & 0.9 & 0.9 & 2.2 & 0.3 & 1.0 & 12.0 & 8.5 & 0.46 \\
\hline
\end{tabular}

Table 3.--Continued. 